\title{
Alternating diatomaceous and volcaniclastic deposits in Milos Island, Greece. A contribution to the upper Pliocene-lower Pleistocene stratigraphy of the Aegean Sea
}

\author{
José P. Calvo ${ }^{\mathrm{a}} *$, Maria V. Triantaphyllou ${ }^{\mathrm{b}}$, Manuel Regueiro ${ }^{\mathrm{c}}$, Michael G. Stamatakis ${ }^{\mathrm{b}}$ \\ a Department of Petrology and Geochemistry, Universidad Complutense de Madrid, Jose Antonio Novais 2, 28040 Madrid, Spain \\ ${ }^{\mathrm{b}}$ Faculty of Geology and Geoenvironment, National and Kapodistrian University of Athens, Panepistimiopolis, 15784 Athens, Greece \\ c Instituto Geologico y Minero de España, Rios Rosas 23, 28003 Madrid, Spain
}

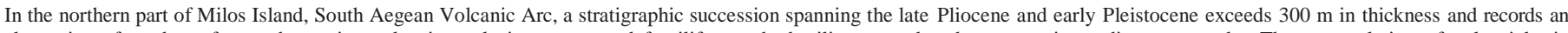

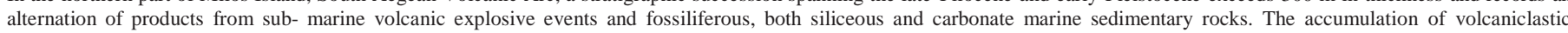
deposits took place under subaqueous marine conditions as evidenced by sedimentary features, scarce fossil remains and the local presence of burrow traces.

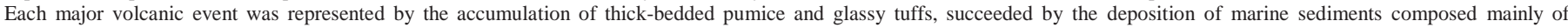

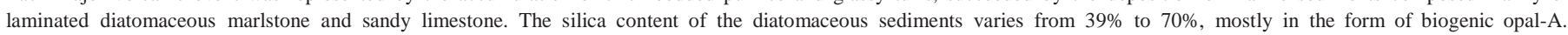

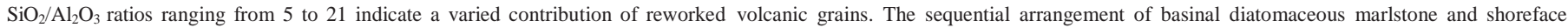
sandy lime- stone deposits suggests that the depth of water was not great, which is also consistent with features observed in the volcaniclastic deposits.

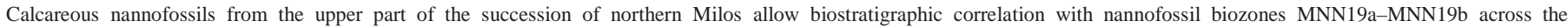

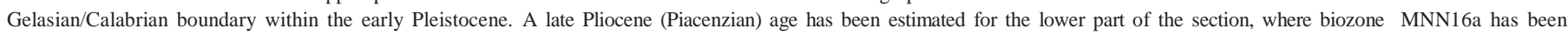

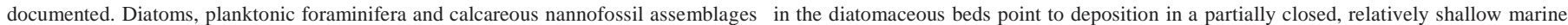

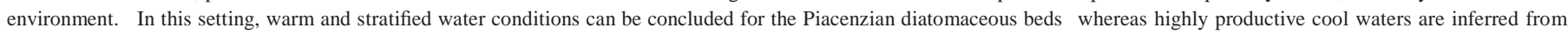
the Gelasian/Calabrian diatomite.
\end{abstract}

Keywords: Diatomaceous marlstone; Volcaniclastic rocks; Calcareous nannofossils; Quaternary; South Aegean Volcanic Arc (SAVA)

\section{Introduction}

The island of Milos is located in the active South Aegean Volcanic Arc (SAVA) (Fig. 1). The SAVA is punctuated by several islands where extensional and subduction-related tectonics as well as a complex history of volcanic episodes throughout the Pliocene and Quaternary is recorded (Angelier et al., 1982; Jackson, 1994; Fytikas and Vougioukalakis, 2005). In Milos Island, volcanic activity started during the late Pliocene (Fytikas et al., 1976; Stewart and McPhie, 2003b, 2006) and is currently represented by high heat flow, thermal springs and the presence of hot soils in the SE part of the island (Fytikas, 1977; Fytikas et al., 1986).

Comprehensive information on the recent geological evolution of Milos was first furnished by Fytikas et al. (1976). However, the timestratigraphic framework of Milos had remained relatively poorly

\footnotetext{
* Corresponding author. Tel.: +34913944902; fax:+34915442535.

E-mail addresses: jpcalvo@geo.ucm.es (J.P. Calvo), mtriant@geol.uoa.gr (M.V.Triantaphyllou),m.regueiro@igme.es (M. Regueiro), stamatakis@geol.uoa.gr (M.G. Stamatakis).
}

established until recent work by Rinaldi and Campos Venuti (2003), who studied the volcaniclastic facies related to the eruption of the Bombarda volcano in the northern part of the island in detail, and by Stewart and McPhie (2003a, 2004). The latter authors provided a stratigraphic framework for the Neogene formations cropping out in the north-eastern sector of the island and proposed an interpreta- tion of some specific volcanic features, e.g. dacite cryptodomes and coarse pumice breccias, included in the Neogene section. Later on, Stewart and McPhie (2006) published an overview of the upper Pliocene and Pleistocene felsic volcanic architecture of Milos Island, reflecting contrasts in eruption style, proximity to source, deposi- tional environment and emplacement processes.

In this paper, a stratigraphic and sedimentological study of the lithological succession cropping out in the area of Alimia-Sarakiniko, northern Milos Island (Figs. 1 and 2), is presented. The stratigraphic succession, which covers the upper Pliocene and lower Pleistocene, can be studied in coastal cliffs and adjacent inland areas starting near Mandrakia and ending about $1 \mathrm{~km}$ east of Sarakiniko (Fig. 2).

Diatomaceous marlstone constitutes a dominant facies throughout the succession. Except for the biostratigraphic work by Frydas (1992, 


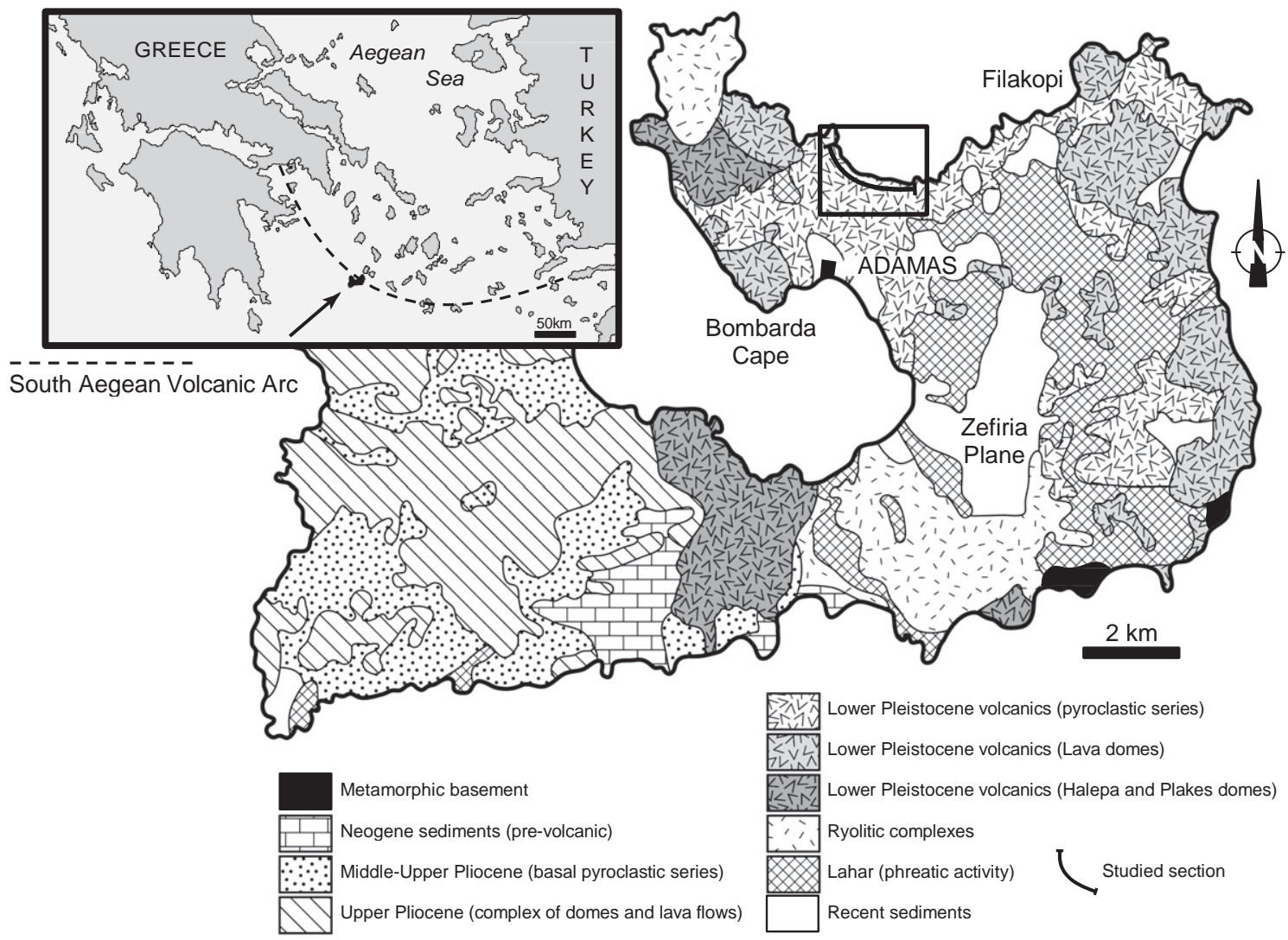

Fig. 1. Geological map of Milos Island (after Fytikas et al., 1986) situated in the west-central part of the South Aegean Volcanic Arc (SAVA) (rectangle). The study area (boxed) is located on the northern part of the island.

1996a, 1996b) and Bellas and Frydas (1994), the presence of diatoma- ceous deposits in the Plio-Pleistocene stratigraphic record of Milos Island has been poorly documented. Stamatakis et al. $(1996,2010)$ and Stamatakis (2003) underlined the occurrence of these deposits but did not provide details about stratigraphic and/or sedimentolog- ical features. Analysis of the sedimentological, mineralogical, and geochemical features of the diatomaceous marlstone and associated sedimentary rocks provides valuable insight into the complex evolu- tionary geological framework of northern Milos for the late Pliocene and early Pleistocene. Moreover, micropalaeontological analysis of this facies contributes to its biostratigraphic assignment on the basis of the calcareous nannofossil assemblages.

\section{Geologicalsetting}

Milos belongs to the Cyclades, a group of islands ${ }_{s}$ forming part of the South Aegean Volcanic Arc (Fig. 1). This volcanic cksain consists of widely spaced centres in which volcanism is predominantly high-K calc-alkaline (Le Pichon and Angelier, 1979; Zeilinga de Boer, 1989; Francalanci et al., 2007). There is general agreement that the develop- ment of the volcanic arc took place throughout the Pliocene and Quaternary as a result of the relative motion of the African and the Aegean plates that gave place to the Hellenic subduction zone (McKenzie, 1978; Le Pichon and Angelier, 1979; Angelier et al., 1982; Meulenkamp et al., 1988; Pe-Piper and Piper, 1989, 2005; Royden and Papanikolaou, 2011).

The geology of Milos was first described by Sonder (1924) and then studied in detail by Fytikas et al. (1976), (1986), Fytikas (1977), and Fytikas and Vougioukalakis (1995). The oldest rocks cropping out in Milos consist of basement metamorphic rocks including mainly schist, gneiss and quartzite of Mesozoic to Palaeogene ages (Fytikas et al., 1976; Fytikas, 1977). The metamorphic basement is overlain unconformably by upper Miocene to lower Pliocene conglomeratic and calcareous rocks (Fig. 1). Prior to the onset of volcanism, subsidence related to extension of the Aegean lithosphere took place during the early Pliocene, between 5.0 and 4.4 Ma (van Hinsbergen et al., 2004).

From the late Pliocene ( $3.0 \mathrm{Ma}$ ), the island of Milos has been affected by extensive calc-alkaline volcanism, leading to a complex arrangement of volcanic and volcano-sedimentary deposits of various ages (Fytikas et al., 1986). The volcanic rocks of Milos are mainly rhyolite and dacite with subordinate andesite and basaltic andesite. Fytikas (1977) and Fytikas and Vougioukalakis (1995) distinguished the basal pyroclastic series composed of mainly felsic, pumice-rich flows, tuffs and tuffites with interbedded sedimentary rocks con- taining marine fauna. This lower volcanosedimentary succession was succeeded by domes and lava flows of rhyolitic to andesitic composition, accompanied by ejection of pyroclastic materials and ignimbrites. Huge lahar deposits (“Green lahar" of Fytikas, 1977) accumulated later in the western part of Milos. More recent periods of strong volcanic activity are recorded by rhyolite to rhyodacite lavas, pumice and cinders. Fytikas et al. (1976) dated these younger volcanic events at $0.48 \mathrm{Ma}$, which represents the time of the most recent eruptive phase in Milos and surrounding islets. Additional dating of the volcanic succession in Milos was provided by Fytikas et al. (1986), Traineau and Dalabakis (1989), Kondopoulou and Pavlides (1990), and Stewart and McPhie (2003a, 2003b, 2004). Re- cently, Rinaldi and Campos Venuti (2003) and Stewart and McPhie (2006) summarised the radiometric ages available from the volcanic units in the northern part of Milos.

The tectonic structure of the island is characterised by a rather dense network of normal faults oriented approximately N-S, E-W and SW-NE. Lava domes and craters are essentially distributed according to this main fault framework (Fytikas et al., 1986; Fytikas and Vougioukalakis, 1995). 


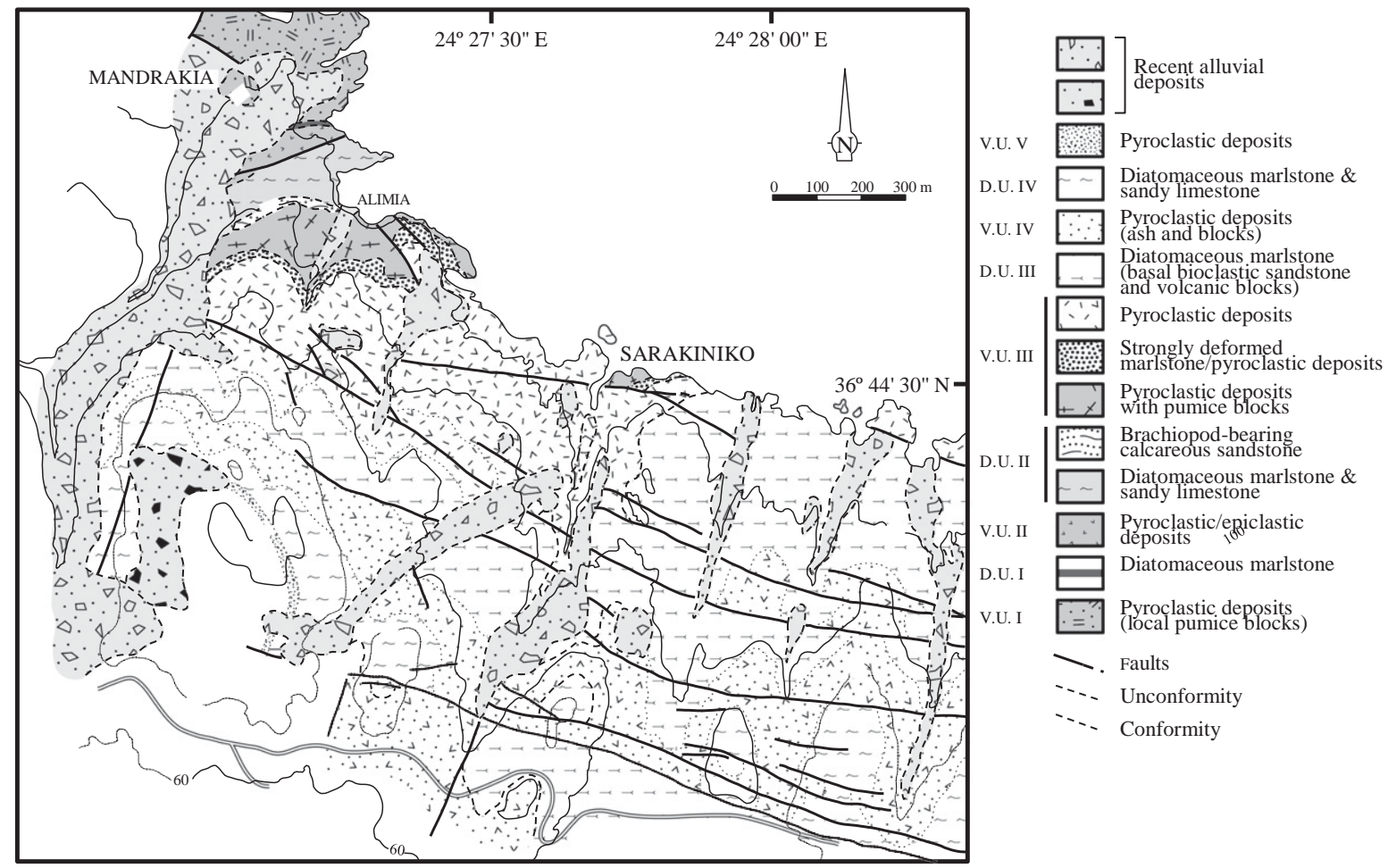

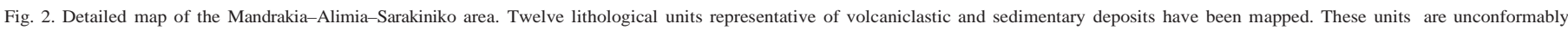

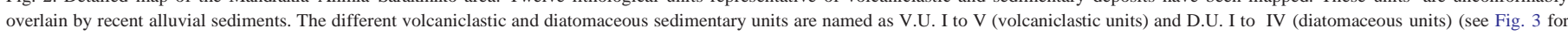
location of these units throughout a general lithostratigraphic log).

\section{Materials and methods}

The present study focuses on the diatomaceous marlstone and associated sedimentary facies that alternate with packages of volca- niclastic rocks in the northern part of Milos (Fig. 2). The stratigraphic succession reaches up to $300 \mathrm{~m}$ in thickness and is included in the "lower volcaniclastic series" (also named "basal pyroclastic series") of Fytikas (1977). Rinaldi and Campos Venuti (2003) described these rocks as generally "marine fossiliferous sandstone”.

Mapping of the area at 1:5000 scale allowed for the reconstruction of the lithostratigraphic framework for the deposits. Such detailed mapping was needed in view of the complex tectonic structure of the area, characterised by a dense network of normal faults. Two main fault groups, oriented $15^{\circ}$ and $115^{\circ}$, form the basic tectonic pattern together with a W-E stretched normal fault near Sarakiniko and some $80^{\circ}$ oriented faults in the proximities of Mandrakia (Fig. 2). These faults define a subsiding area between Adamas, Sarakiniko, and the Zefiria Plain (Fig. 1) (Rinaldi and Campos Venuti, 2003).

Twelve superposed map units, covered unconformably by recent alluvial sediments (Fig. 2), have been differentiated. These map units can be integrated into a general lithostratigraphic column that ex- ceeds $300 \mathrm{~m}$ thickness and comprises five lithologic units composed of volcaniclastic rocks and four lithological units that consist mainly of diatomaceous marlstone and sandy limestone (called 'diatomite units' in Fig. 3).

Eighty two samples were collected for petrographic analysis under polarised light microscope, 25 of them also analysed by scanning elec- tron microscope (SEM) imaging (Jeol JSM-6400 and Hitachi 5400 field transmission apparatus). X-ray diffraction was used to deter- mine mineral composition in powdered sandy limestone and dia- tomaceous marlstone. Chemical analysis of major elements in 35 samples was performed by X-ray fluorescence.

In addition, 28 samples were analysed for calcareous nannofossil content. Smear slides were prepared for each sample using standard techniques (Perch-Nielsen, 1985). Analyses were performed using a Leica DMSP polarising light microscope at $1250 \times$ magnification, by counting at least 300 specimens per sample; counts of index species were converted into percentages. For very rare species, e.g. discoast- erids, up to 1500 fields of view were examined in randomly distrib- uted longitudinal transverses per slide. Semiquantitative analysis in 15 fields of view was applied for the very small species such as

Gephyrocapsa spp. b3 $\mu \mathrm{m}$ and Florisphaera profunda. Zonal assignments of the nannofossil content follow the zonal scheme of Rio et al. (1990), incorporating updates by Lourens et al. (2004) and Raffi et al. (2006).

Twenty-three samples of diatomaceous marlstone rocks were collected and processed for fossil diatom study under SEM. Nine of them were not used for the study as they did not contain sufficient diatom forms. Distinction was made between subsamples derived from light and dark laminae in order to assess differences in the content of diatoms, clays and/or other components.

Twelve marlstone samples were washed through a 200 mesh sieve and analysed for their foraminiferal content under binocular microscope.

\section{Lithostratigraphy}

Nine lithostratigraphic units have been distinguished in the upper Pliocenelower Pleistocene succession of northern Milos (Fig. 3). The units have been differentiated on the basis of the dominant lithologies that consist of (i) fossiliferous sedimentary rocks consisting of marl- stone and limestone with varied amounts of reworked volcanic grains and (ii) volcaniclastic rocks mostly composed of pumiceous materials. The marlstone deposits are mainly diatomaceous and include a variety of diatom, foraminifera and calcareous nannofossil assem- blages that contribute significantly to both palaeoenvironmental interpretation and dating of the stratigraphic succession. 


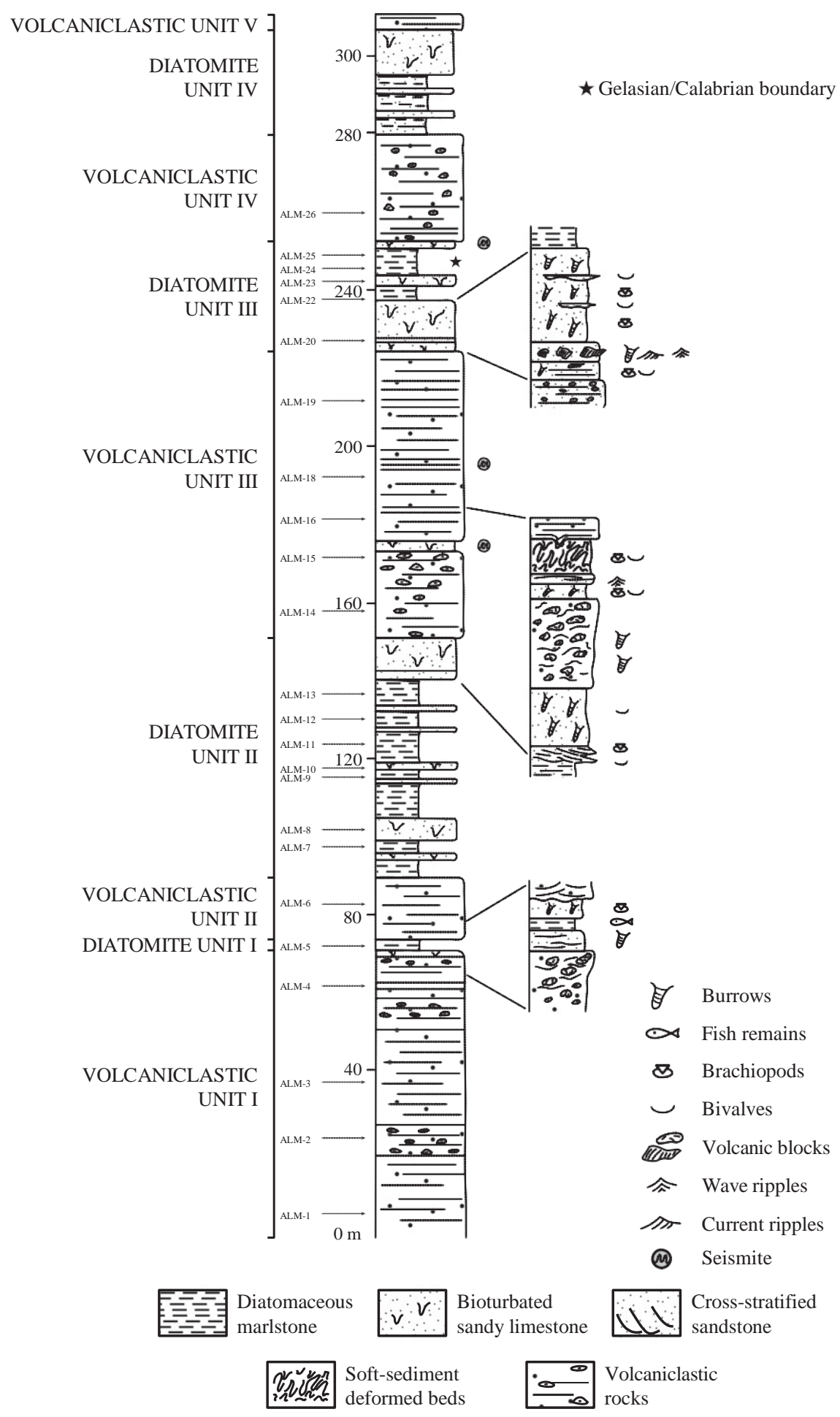

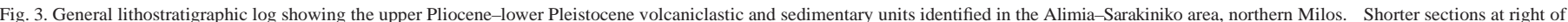

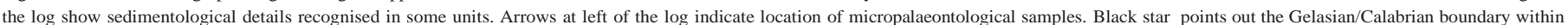
Diatomite Unit III.

\subsection{Fossiliferous sedimentary rocks}

Laminated diatomaceous marlstone alternating with sandy lime- stone constitutes the most common sedimentary facies association in all diatomite units throughout the whole succession. In total, 14 sedimentary cycles formed of diatomaceous marlstone and sandy limestone beds were measured. Thicknesses of the sedimentary couplets are variable, ranging from 2.5 to $10.5 \mathrm{~m}$. Likewise, thicknesses of the intervening diatomaceous marlstone and sandy limestone beds that form each cycle are also variable. The thickest, up to $9.5 \mathrm{~m}$, diatomaceous marlstone deposit was recognised in Diatomite Unit II (Fig. 4). Laminae in the diatomaceous marlstone are defined by submillimetrethick lithic/biogenic couplets (sensu Sancetta, 1996) (Fig. 5A, B). Usually, the diatomaceous marlstone forms the lower part of the sedimentary cycles and the contact with the underlying sandy limestone is sharp. Upward transition 


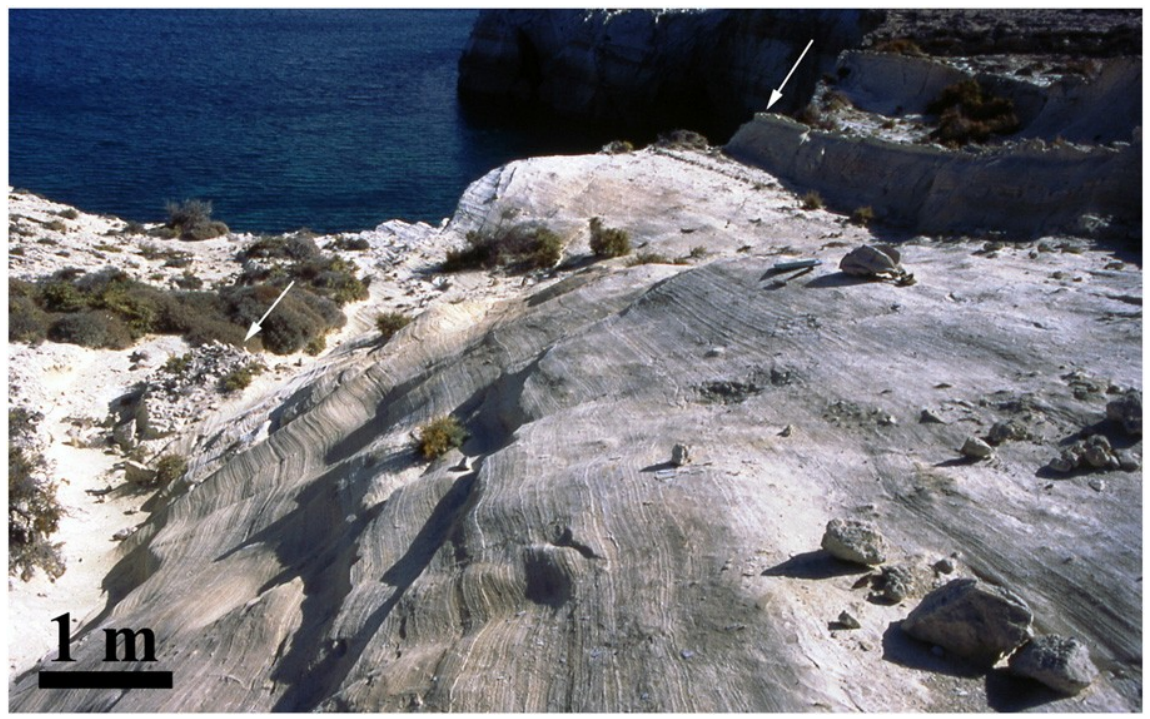

Fig. 4. Outcrop showing laminated diatomaceous marlstone from Diatomite Unit II. Thickness of the bed is up $9.5 \mathrm{~m}$ and the section top is located at right of the picture. Both the bottom and the top of the diatomaceous deposit are marked by sandy limestone beds (arrows).

from diatomaceous marlstone to sandy limestone is rapid grada- tional and is marked by burrow traces (Fig. 6) that become largely developed in the sandy limestone in the upper part of each sedi- mentary cycle.

Cross-stratified, brachiopod-rich (Terebratula spp.) sandstone beds (Fig. 7) occur in the upper part of Diatomite Unit II (Fig. 3). A wave-rippled sandstone and siltstone bed showing well-developed burrow traces (Fig. 8) occurs at the base of Diatomite Unit III (Fig. 3). Although these lithofacies are only locally present in the succession, they are indicative of relevant stratigraphic events of the geological evolution of Milos during the late Pliocene and early Pleistocene (see discussion below).

Table 1 provides a description and interpretation of the several lithofacies distinguished from fossiliferous sedimentary rocks in the stratigraphic succession of northern Milos.

\subsection{Volcaniclastic rocks}

In this paper, the term 'volcaniclastic' is used in a simple descrip- tive way to name rocks composed chiefly of grains of volcanic origin, derived from contemporaneous volcanicity (Tucker, 2001) and that result from any mechanism of fragmentation (Vincent, 2000). The stratigraphic section in northern Milos records mainly volcaniclastic rocks related to submarine felsic cryptodome-pumice cone volcanoes (Stewart and McPhie, 2006). Products from this type of submarine volcanism are largely represented by white to cream pumiceous deposits with subordinate occurrence of dark lithic fragments that record a long history of explosive eruptions (Rinaldi and Campos Venuti, 2003).

The five volcaniclastic units distinguished throughout the upper Pliocene-lower Pleistocene succession of northern Milos (Fig. 3) are composed of volcaniclastic rocks that display features indicative of deposition in a submarine setting (Table 2). Maximum thickness of the volcaniclastic units was measured in Volcaniclastic Unit III, where three superposed packages of volcanic products bounded by un- conformities and/or truncations reach up to $75 \mathrm{~m}$ (Fig. 3).

Sedimentary structure, scarce fossil remains and burrow traces, and the presence of fossiliferous deposits above and below the pumice packages strongly suggest accumulation under dominantly below- wave-base conditions. In this setting, the volcanic products were distributed by submarine currents and/or gravitational flows pro- cesses close to the volcanic submarine source centres (Table 2).

The structure of the volcaniclastic rocks varies from massive to wellbedded. Massive volcaniclastic deposits usually formed of coarse breccia occur in Volcaniclastic Units I, II and III (Fig. 9A) whilst Volcaniclastic Units IV and V are composed of better stratified de- posits (Fig. 9B). These changes of volcaniclastic units up succession can be interpreted as reflecting the evolution from submarine to very shallow even subaerial volcanism throughout the late Pliocene to Pleistocene in most of Milos Island, an idea already suggested by Stewart and McPhie (2006).

Sand- to silt-sized volcanic grains are a common component of the fossiliferous sedimentary rocks alternating with volcaniclastic deposits in northern Milos. Besides this occurrence, big volcanic blocks ranging from 0.20 to $4.40 \mathrm{~m}$ in diameter occur isolated and aligned at the base of Diatomite Unit III (Fig. 3). The volcanic blocks overlie wave-rippled sandstone and siltstone deposits and together form a key-bed that can be followed for a few hundreds of metres east of the Sarakiniko canyon.

\subsection{Seismic imprint resulting in soft-sediment structures}

Both fossiliferous sedimentary rocks and volcaniclastic deposits display soft-sediment deformation structures. The deformation struc- tures consist of i) burrowing-related deformation that mainly affects laminated diatomaceous marlstone, ii) deformation structures due to loading (Owen, 1996), and iii) soft-sediment deformation struc- tures of probable seismic origin, i.e., seismites (Collinson, 1994).

Loading is considered the usual triggering mechanism of softsediment deformation structures in the volcaniclastic deposits of northern Milos. Disturbance of well-bedded fine-grained pumiceous deposits by loading of coarse-grained, rapidly accumulated volcani- clastic material under subaqueous conditions resulted in convolute bedding and flame and pillow-like structures (Fig. 10).

Soft-sediment deformation structures interpreted as seismically induced are present at certain intervals of the upper Pliocene-lower Pleistocene succession. At least three main horizons, occurring at $175 \mathrm{~m}, 195 \mathrm{~m}$ and $255 \mathrm{~m}$ from the bottom of the section (Fig. 3), display clear earthquakerelated deformation structures. The seismite beds are composed both of fossiliferous diatomaceous marlstone 
A

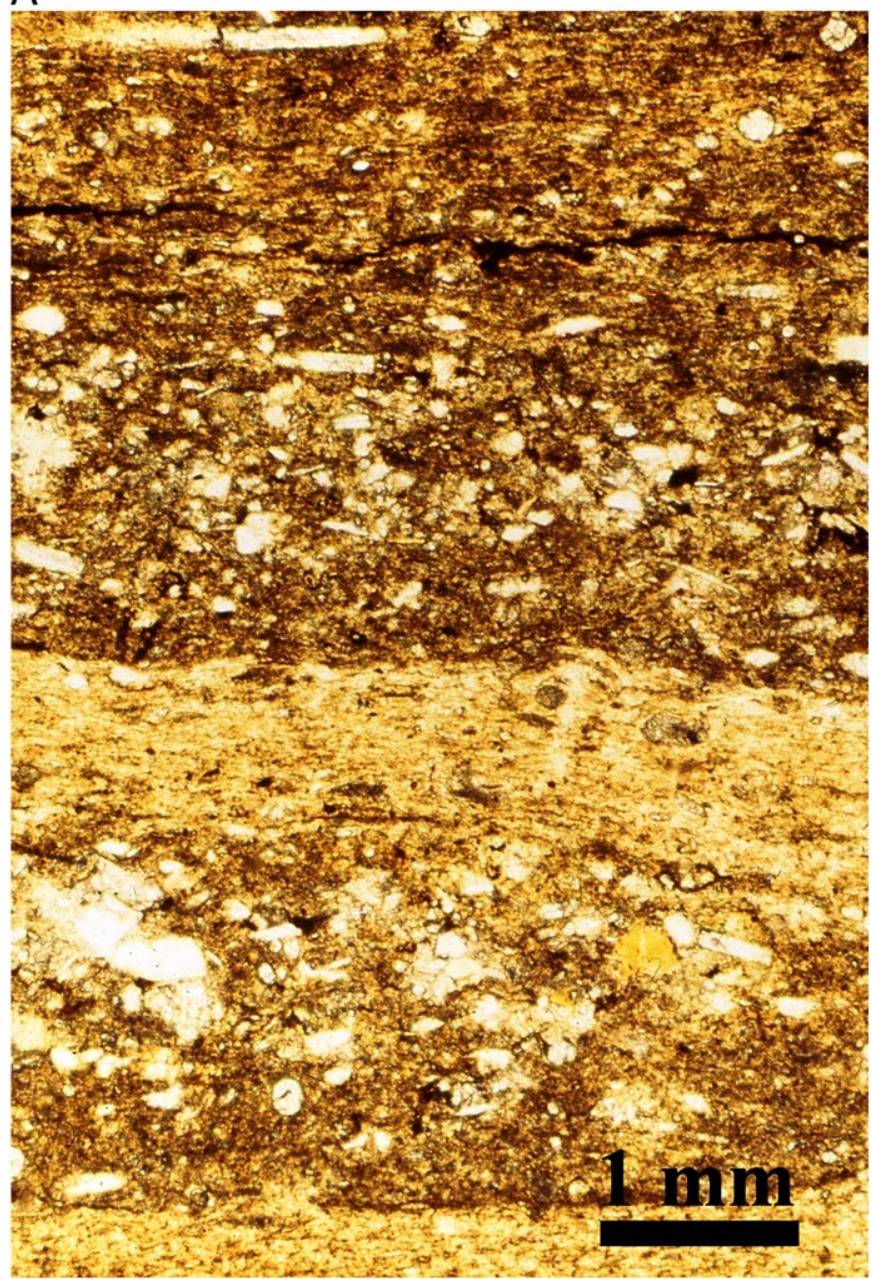

B

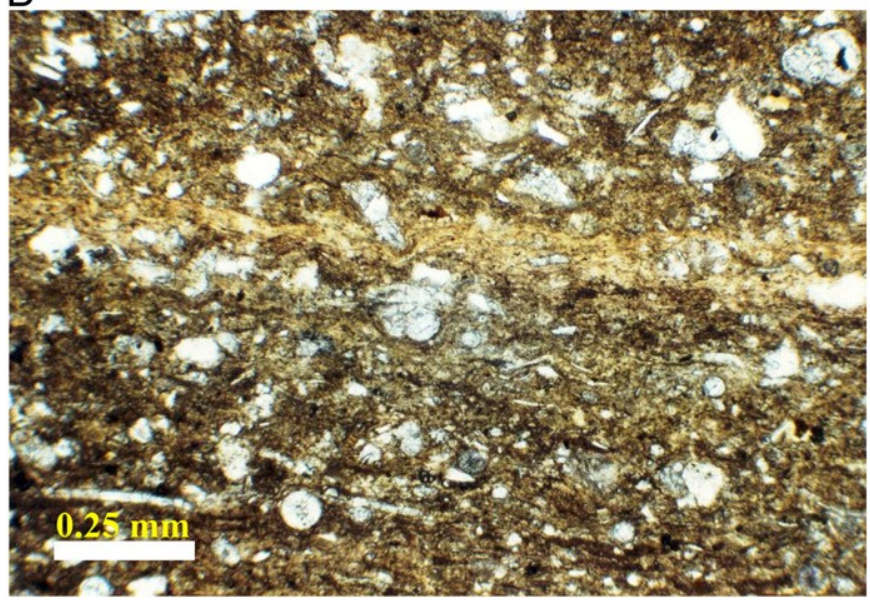

Fig. 5. A: Photomicrograph of diatomaceous marlstone. Dark lithic laminae contain abundant grains of volcanic origin and exhibit a sharp contact with underlying lighter biogenic laminae composed mainly of diatom frustules. B: Volcanic grains mixed with forams and sponge spicules in lithic laminae.
5. Micropalaeontology and age framework of the Alimia-Sarakiniko sequence

Results from the calcareous nannofossil analysis of diatomaceous marlstone samples (Fig. 3) are summarised in Table 4. Samples ALM2a to ALM6 from Diatomite Unit I and ALM14 to ALM20 from Diatomite Unit II were barren while sample ALM9 contained only diatom microfossils. The rest of the collected samples contained both diatom- and calcareous nannofossil-rich assemblages. Quantita- tive analysis of samples ALM7 to ALM12 from Diatomite Unit II shows common Helicosphaera sellii, Calcidiscus macintyrei, Pseudoemiliania lacunosa, Braarudosphaera bigelowii and very rare small Gephyrocapsa spp. (Fig. 12). Discoaster spp. are also very rare, represented by few specimens of $D$. asymmetricus, $D$. tamalis and $D$. triradiatus per sample (Table 4; Plate I). Semiquantitative analysis documented abundant Florisphaera profunda. Sample ALM22 contains $H$. sellii, C. macintyrei,

$P$. lacunosa and abundant small Gephyrocapsa spp. However, discoast- erids and normal size gephyrocapsids (Gephyrocapsa spp. $>4 \mu \mathrm{m}$ ) were not detected. The first unambiguous representatives of $>4 \mu \mathrm{m}$ Gephyrocapsa spp. occur in samples ALM23-26 from Diatomite Unit III(Plate I; Fig. 3).

A rich foraminiferal assemblage (Table 4) composed of Globigerina bulloides, G. falconensis, G. quinqueloba, Globigerinoides ruber, Neogloboquadrina pachyderma, Orbulina universa and Lobatula lobatula is a feature of the samples from Diatomite Unit II. However, no traces of Sphaeroidinellopsis spp. have been recorded. Foraminiferal assem- blages in Diatomite Unit III are dominated by Globigerinoides saculifer, Globigerinella aequilateralis, and Globorotalia inflata. Samples collected in Diatomite Unit IV show abundant benthic foraminifers but very sparse planktonic forms (Globigerina bulloides, G. quinqueloba, G. falconensis, Globigerinoides ruber and Neogloboquadrina pachyderma). The diatom assemblages (Table 4) from Diatomite Unit I contain abundant Rophadolia, Actinocyclus spp., and Rhizosolenia and Gram- matophora in both light and dark laminae whilst Coscinodiscus and Thalassionema nitzschioides are more common in the light laminae. Diatomaceous sediments from Diatomite Unit II show a variety of diatom forms with abundant Rophadolia, Thalassionema, Rizhosolenia, Thalassiosira, Nitzschia, Hemidiscus, Cyclotella, and Actinocyclus, mostly in the light laminae. Samples collected from Diatomite Units III and IV contain a similar diatom assemblage with abundant Stephanopyxix and Amphora forms.

Several beds exposed in the area are well-known at a regional scale because of both richness and good preservation of macrofossils. This is the case for a palaeontological site close to Sarakiniko (Sonder, 1924) that yields a rich fossil association of bivalves (Chlamys spp., Pecten, Isocardia, Solecardia, Pinna, Ostrea, Chama, Lucinopsis), scapho- pods (Dentalium), gastropods (Scala), brachiopods (Terebratula spp.), echinoids (Arbacina, Psammechinus, Schizaster, Lytechinus, Brissopsis, Prostagantus), and barnacles (Table 4).

Fytikas et al. $(1976,1986)$ and Fytikas and Vougioukalakis (1995) indicated that accumulation of the "lower volcaniclastic series" possi- bly started during the middle Pliocene ( $3.4 \pm 3.0 \mathrm{Ma})$. K/Ar dating of a non-juvenile rhyolite clast in submarine pumice breccia suggested a maximum age of $3.08 \pm 0.14 \mathrm{Ma}$ (Fytikas et al., 1986). An upper age limit for the submarine pumice breccias at $\sim 2.66 \pm 0.07 \mathrm{Ma}$ was provided by U/Pb dating of the Filakopi Pumice Breccia (Stewart and McPhie, 2004) and the volcanic activity in the northern part of Milos has been more or less continuous since then (Stewart and McPhie, 2006). SHRIMP U-Pb dating of zircon in one of the oldest subaerial dacite domes (Stewart and McPhie, 2006) yielded an age of $1.44 \pm 0.08$ Ma. This suggests that the subaerial part of the vol- canic succession in northern Milos Island began at that time in re- sponse to a combination of volcanic constructional processes and fault-controlled volcano-tectonic uplift (Stewart and McPhie, 2006). Additional age information is provided by a radiometric age of $1.85 \mathrm{Ma}$ on biotite from a dacite pumice clast collected in the pyroclastic
(Fig. 11) and laminated pumice ash. Each of the three strongly deformed beds is overlain by volcaniclastic units that record new episodes of explosive volcanism. This stratigraphic relationship sup- ports that the deformation of the underlying deposits was triggered by earthquakes taking place prior to eruptive events (Jones and Omoto, 2000; Schminke, 2004). 


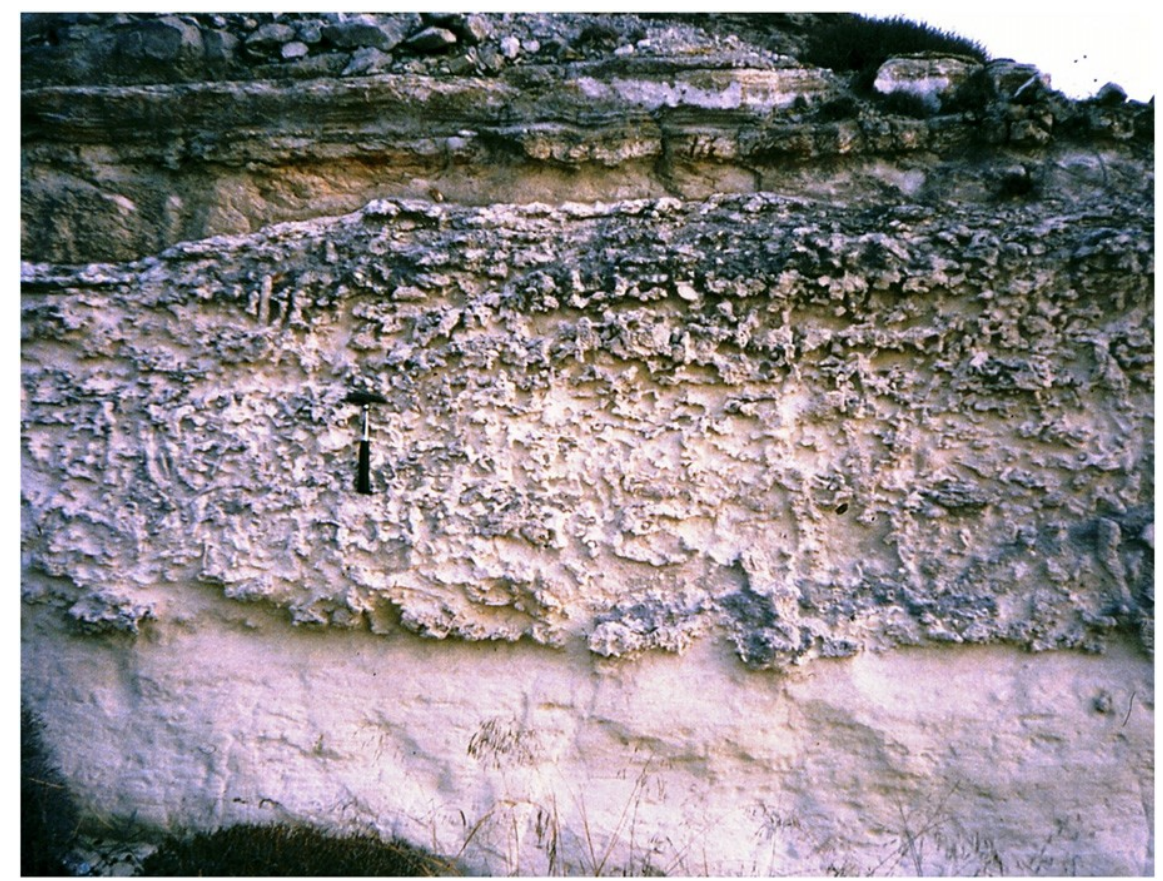

Fig. 6. Outcrop view of massive, strongly burrowed sandy limestone capping a diatomaceous marlstone-sandy limestone cycle at the top of Diatomite Unit III. Hammer for scale is 30 cm long.

deposits of this series cropping out near Sarakiniko (Fytikas et al., 1986). Kondopoulou and Pavlides (1990) determined an age of

1.8 Ma for an andesite lava flow (Korakia Andesite of Stewart and McPhie, 2003a) overlying the Sarakiniko deposits. A younger radio- metric age (1.6 $\mathrm{Ma}$ ) for the lava domes overlying the lower series to the east of the study area was provided by Fytikas et al. (1986), which yields an upper age limit for the succession analysed in northern Milos.

Regarding the fossiliferous sedimentary rocks of northern Milos, Sonder (1924) initially suggested a late Pliocene age for the rich macrofossil assemblage in calcareous beds occurring near Sarakiniko (see fossil content in a previous paragraph). Later on, Fytikas (1977) suggested a possible middle Pliocene age for those beds on the basis of planktonic foraminiferal assemblages, although these were lacking biostratigraphic indices. According to the new evidence provided by calcareous nannofossils from samples collected in the lower part of Diatomite Unit III (Fig. 3), the diatomaceous and calcareous de- posits of this unit are biostratigraphically correlated with MNN19a- MNN19b nannofossil biozones, spanning a time interval between

1.95 and 1.73 Ma (Lourens et al., 2004), so their age must be changed to Gelasian/Calabrian (formerly late Pliocene, currently early Pleis- tocene; Gibbard et al., 2009; Papanikolaou et al., 2011). This fits well earlier work by Frydas (1992, 1996a) who on the basis of sili- coflagellates and diatoms dated the SE-Adamas fossiliferous site as early Pleistocene. Unequivocal stratigraphic correlation of this fossiliferous site with the third uppermost diatomaceous marlstone- sandy limestone cycle of Diatomite Unit III can be established by tracing the cyclically arranged beds from Sarakiniko to SE Adamas.

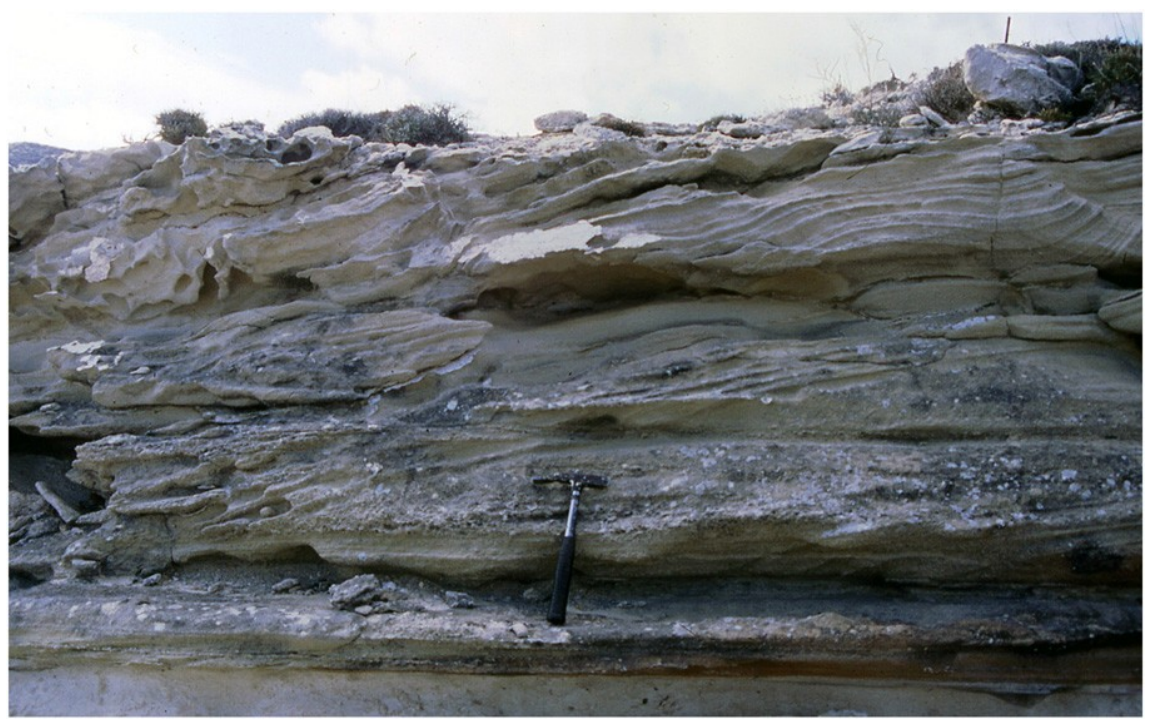

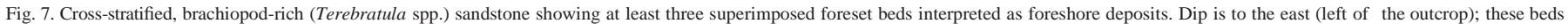
occur near the top of Diatomite Unit II. Hammer for scale is $35 \mathrm{~cm}$ long. 


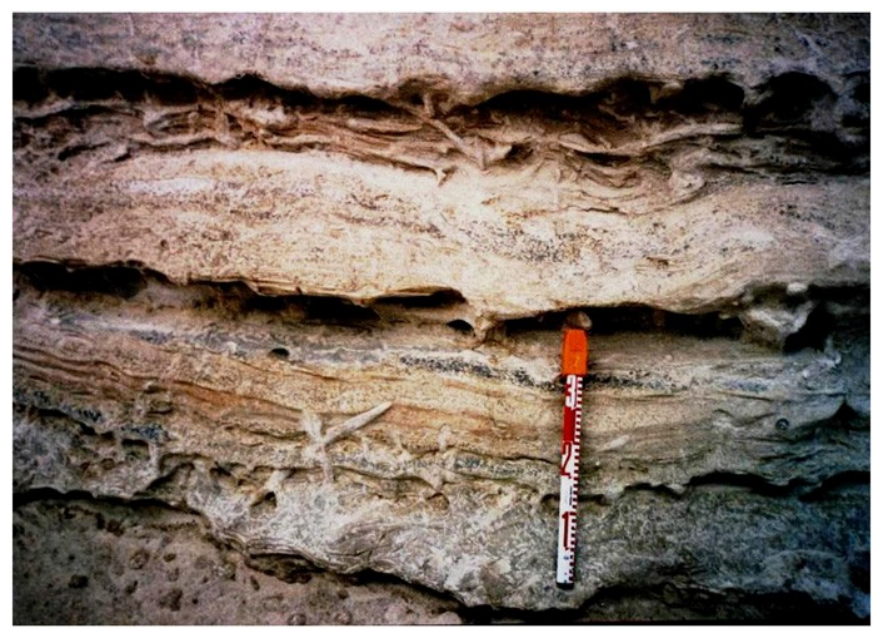

traces (Thalassinoides)

The rest of the stratigraphic succession studied in northern Milos, including Diatomite Unit IV, is correlated to nannofossil biozone MNN19b of early Calabrian age.

The biostratigraphic assignment of Diatomite Unit II to nanno- fossil biozone MNN16a (Rio et al., 1990), particularly in between the highest occurrence of Discoaster asymmetricus (2.83 Ma, Lourens et al., 2004) and the highest occurrence of Sphaeroidinellopsis spp. (3.19 Ma, Lourens et al., 2004) supports a late Pliocene (Piacenzian) age for the lower part of the AlimiaSarakiniko stratigraphic succession.

6. Palaeoenvironmental reconstruction and major events during the late Pliocene-early Pleistocene in northern Milos

Except for some horizons of Diatomite Unit II, where cross-stratified, brachiopod-rich (Terebratula spp.) sandstone shows features indicative of very shallow-marine depositional conditions, most of the upper Pliocene-lower Pleistocene rocks in northern Milos formed mostly.

Fig. 8. Wave-rippled sandstone and siltstone showing parallel to oblique oriented burrow

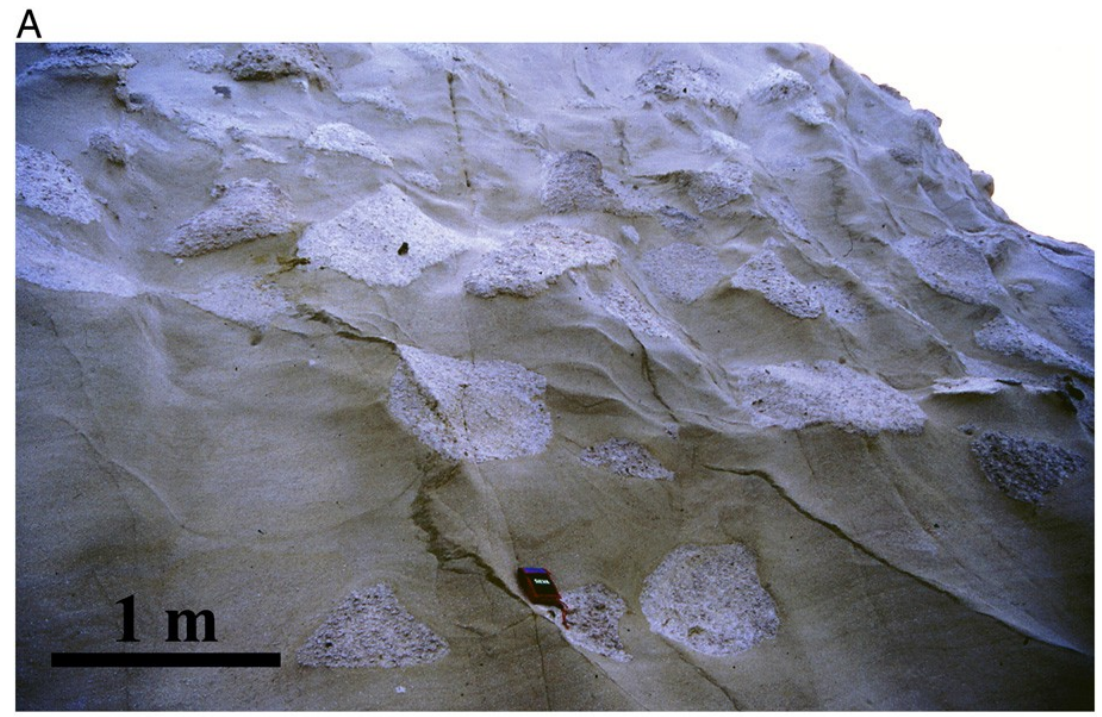

B

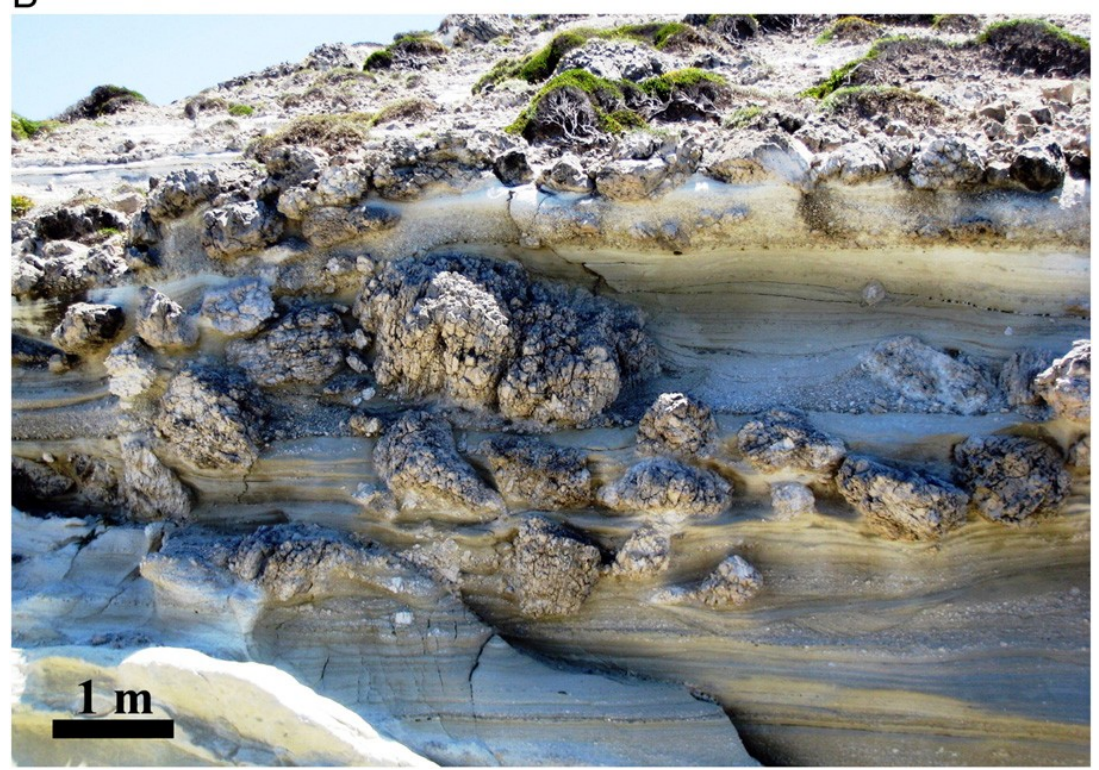

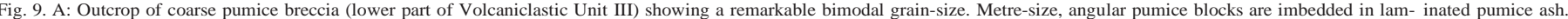

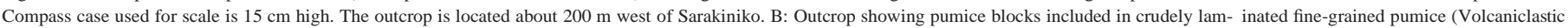
Unit IV); the outcrop is located east of Sarakiniko. 


\begin{tabular}{|c|c|c|}
\hline Facies & Description & Interpretation \\
\hline \multirow{5}{*}{$\begin{array}{l}\text { Laminated diatomaceous marlstone } \\
\text { Present in all diatomite units. Fourteen } \\
\text { diatomaceous marlstone horizons } \\
\text { alternating with massive sandy limestone } \\
\text { were measured in the } \\
\text { section. Bed thickness ranges } 1.20-9.50 \mathrm{~m} \text {. }\end{array}$} & $\begin{array}{l}\text { Sedimentary features and bioclastic components: } \\
\text { Millimetre-thick laminated to locally banded, white to light-grey beds. Laminae are defined by } \\
\text { submillimetre-thick lithic/biogenic couplets (Fig. } 5 \mathrm{~A} \text { ). }\end{array}$ & $\begin{array}{l}\text { Deposition below the zone of wave influence. Alternating episodes of } \\
\text { detrital input followed by periods of maximal, probably seasonally- controlled }\end{array}$ \\
\hline & $\begin{array}{l}\text { Dark lithic couplets composed of fine-grained sand and silt, medium- to poorly- sorted volcanic } \\
\text { glass fragments, with minor quartz and feldspar grains in clayey- calcareous micrite. Planktonic } \\
\text { and benthic foraminifera, ostracod shells, and sponge spicules occur mixed with the siliciclastic }\end{array}$ & $\begin{array}{l}\text { Depositional setting characterized by oxygen-deficient bottom waters resulting from } \\
\text { water stratification in a partially closed, relatively shallow sea. Palaeogeographic } \\
\text { features determined by development of silled basins (Fig. 13). }\end{array}$ \\
\hline & $\begin{array}{l}\text { grains (Fig. 5B). } \\
\text { Light biogenic laminae formed of dense aggregates of large, usually broken frustules of } \\
\text { planktonic diatoms and siliceous sponge spicules. }\end{array}$ & $\begin{array}{l}\text { Input of lithic detritus by dilute turbidite flows to the basin (coincident with periods } \\
\text { of runoff and/or aeolian transport). Terrigenous influx related to reworking of pre- } \\
\text { existing basin deposits. }\end{array}$ \\
\hline & $\begin{array}{l}\text { Occurrence of both complete skeletons and scales from undetermined fish species. Presence of } \\
\text { large, isolated burrow patches (Ophiomorpha? sp.) leading to local soft- sediment deformation. } \\
\text { Intercalations of up to } 2 \mathrm{~cm} \text { thick layers of massive to slightly graded marlstone formed of clay } \\
\text { aggregates, lithic, and bioclastic grains floating in micrite matrix. Thicker beds of the massive } \\
\text { marlstone occur at the gradational transition into sandy limestone. }\end{array}$ & $\begin{array}{l}\text { Diatom and calcareous nannofossil assemblages (Table 4; Fig. 11) characteristic of } \\
\text { high productivity periods. Biosiliceous productivity probably related to local } \\
\text { upwelling of nutrient-rich waters and/or input of terrestrial nutrients. } \\
\text { Occurrence of some calcareous nannofossils, i.e. Braarudosphaera spp., } \\
\text { indicative of freshwater input during deposition of the diatomaceous marlstone and } \\
\text { proximity of land source areas. }\end{array}$ \\
\hline & $\begin{array}{l}\text { Chemical and mineralogical composition: } \\
\text { Whole-rock } \mathrm{SiO}_{2} \text { concentrations variable from } 35 \text { to } 71 \% \mathrm{SiO}_{2} \text { (Table 3). } \mathrm{SiO}_{2} / \mathrm{Al}_{2} \mathrm{O}_{3} \text { ratio } \\
\text { ranging from } 5 \% \text { to } 28 \% \text {. }\end{array}$ & $\begin{array}{l}\text { Large Ophiomorpha? sp. burrow traces interpreted as living conduits (Domichnia) of } \\
\text { decapod crustaceans. Local development of burrowing infauna related to episodes of } \\
\text { improved benthic oxygenation in a depositional environment characterised by } \\
\text { oxygen-deficient conditions. }\end{array}$ \\
\hline
\end{tabular}

Massive sandy limestone

Present in all diatomite units, usually alternating with laminated marlstone. Up to $20 \mathrm{~m}$ thick sequences of massive sandy limestone occur in Diatomite Units II and III.

Cross-stratified, brachiopod-rich (Terebratula spp.) sandstone

Present in the upper part of Diatomite Unit II. Formed of foreset beds dipping $\sim 20^{\circ} \mathrm{ESE}$

Wave-rippled sandstone and siltstone

Present in the lower part of Diatomite Unit III. Key-bed (up to $0.80 \mathrm{~m}$ thick) traceable for a few hundred metres east of Sarakiniko.
opal-A in the dark lithic couplets. No evidence of transformation from opal-A to opal-CT and/or quartz.

Calcite percentage ranging from 0 to $70 \%$ (Table 3). Dolomite does not exceed $5 \%$.

Strongly burrowed sandy limestone beds. No presence of current and/or wave generated sedimentary structures.

Percentage of siliciclastic sand grains (volcanic glass, quartz, and feldspar) ranging from 15 to $40 \%$. Mixing with bivalve, echinoid, brachiopod, benthic and planktonic forams imbedded in calcareous

micrite groundmass.

Large variety of macro and microfossils (mainly benthic forms). Local occurrence of smal oyster patch-reefs.

Occurrence as a package of superimposed $30 \mathrm{~cm}$ thick foreset beds (total thickness of the cross-bedded deposit is $1.50 \mathrm{~m}$ ). The foresets extend up to $20 \mathrm{~m}$ down-dip passing laterally into burrowed sandy limestone. Gently sloped, large channels observable in cross-section. Abundant casts of Terebratula ssp. in sandstone formed of well-sorted, rounded siliciclastic (quartz, volcanic fragments), peloids, and bioclastic (benthic foraminifera, bivalves, echinoids) grains

Oblique to horizontally laminated, wavy-rippled bioclastic sandstone alternating with silty marlstone. Sub-rounded, moderately to well-sorted, medium- to finegrained sandstone and siltstone mainly formed of quartz, volcanic grains, and bioclasts (bivalves, echinoids, benthic forams)

Common occurrence of burrowing (Thalassinoides), both oblique and parallel to the sandstone layers. Burrow traces display two different sizes: most common type is $1-2 \mathrm{~cm}$ wide; less common burrow traces are 3-4 $\mathrm{cm}$ wide.
Deposition in a shallow self to shoreface environment characterized by weloxygenated conditions as indicated by predominance of benthic fossil forms, abundance of siliciclastic grains and lack of sedimentary structures characteristic of turbidity currents.

Burrowing due to bivalves, echinoids and brachiopods.

Deposition in a beach environment (foreshore facies). Terrigenous material supplied by both subaerial and submerged volcanic outcrops. Bioclasts derived mainly from benthic macrofauna living in the littoral zone. Facies transition into burrowed sandy limestone indicative of rapid change from foreshore to shoreface sub-environments.

Deposition under relatively low-energy conditions in a proximal/coastal environmen. Burrow traces representative of both vertical and horizontal living conduits of estomatopod crustaceans. Small size of the burrows supports deposition in a very shallow-water environmen. 
Table 2

Description and interpretation of volcaniclastic rocks in the upper Pliocene-lower Pleistocene succession of northern Milos.

\begin{tabular}{|c|c|c|}
\hline Facies & Description & Interpretation \\
\hline Massive coarse pumice breccia & $\begin{array}{l}\text { Massive, poorly sorted deposit composed of boulder (up to } 3 \mathrm{~m} \text { ) to cobble } \\
\text { pumice clasts set in fine-grained pumiceous and shard-rich matrix (Fig. 8A). The pumice }\end{array}$ & $\begin{array}{l}\text { Submarine water-settled pumice deposit resulting from explosive rhyolitic eruptions. } \\
\text { Facies similar to the pumice breccia described in Filakopi by }\end{array}$ \\
\hline \multirow[t]{2}{*}{ Present in V.U. I, II and III. } & $\begin{array}{l}\text { clasts mainly composed of aggregates of rhyolitic shards and vesicular glass. Matrix- } \\
\text { supported fabric dominant. Remarkable bimodal grain-size distribution. } \\
\text { Pumice clasts usually display reverse grading whereas matrix is internally normally graded. } \\
\text { Subangular to subrounded pumice clasts displaying internal polyhedral joints and quenched } \\
\text { margins. Dense lithic clasts minor or absent. }\end{array}$ & $\begin{array}{l}\text { Stewart and McPhie (2004). } \\
\text { Settling of coarse pumice clasts from suspension and progressive infilling by fine } \\
\text { pumice ash. Pumice clasts were freshly erupted (juvenile clasts). Quenched margins } \\
\text { of coarse pumice clasts indicative of minimal abrasion during transport and } \\
\text { deposition. }\end{array}$ \\
\hline & $\begin{array}{l}\text { Diffusely stratified pumice to shard-rich matrix usually displaying internal normal grading. } \\
\text { Lower contacts are gradational whilst upper contacts are commonly sharp and } \\
\text { planar. Maximum measured thickness } 23 \mathrm{~m} \text {. Low-angle truncation surfaces and scouring } \\
\text { between sets of laminae. Local pumice blocks associated with crescent scours. Mantling of } \\
\text { pumice blocks by ash laminae. } \\
\text { Local burrowing (cm- to dm-sized burrow traces) by macrobenthic infauna. }\end{array}$ & $\begin{array}{l}\text { Accumulation in relatively shallow-marine but dominantly below-wave- base setting. } \\
\text { The shallow-marine depositional conditions are also indicated by occurrence of sparse } \\
\text { infaunal burrowing, benthic fossils and stratigraphic relationship with shallow-water } \\
\text { fossiliferous sedimentary rocks. } \\
\text { Remobilisation of pumice by gravity currents and local mass-flow processes, i.e. } \\
\text { sliding and slumping of pumice bed packages. }\end{array}$ \\
\hline Stratified fine-grained pumice & $\begin{array}{l}\text { Well-bedded pumice-rich depositshowing crudely stratified orlaminated internal } \\
\text { structure. Moderately sorted pumice pebbles (up to } 4 \mathrm{~cm} \text { ) and glass shards are }\end{array}$ & $\begin{array}{l}\text { Deposition of pumice and other juvenile volcanic clasts mainly resulting from water- } \\
\text { settling processes. }\end{array}$ \\
\hline Present in V.U. II and III. & $\begin{array}{l}\text { dominant components. Dense lithic clasts locally present at the lower part of some beds. Beds } \\
\text { show sharp lower and upper contacts (Fig. } 10) \text { and internally display normal to reverse } \\
\text { grading. Bed thickness is variable }(20-80 \mathrm{~cm}) \text {. Rapid bed thinning is common, occasionally } \\
\text { resulting in bed truncation. } \\
\text { Soft-sediment deformation structures are common, especially in finer-grained, shard-rich } \\
\text { deposits (Fig. 10). }\end{array}$ & $\begin{array}{l}\text { Well-developed bedding indicative of punctuated submarine rhyolitic eruptions. } \\
\text { Fine-grained texture and sorting indicative of accumulation in distal areas from the } \\
\text { vent volcanic source. }\end{array}$ \\
\hline $\begin{array}{l}\text { Stratified to laminated ash } \\
\text { and pumice blocks }\end{array}$ & $\begin{array}{l}\text { Thinly bedded to laminated ash composed of pumice fragments and glass shards with } \\
\text { pumice block ( } 0.30-2.40 \mathrm{~m}) \text { concentrations (Fig. } 9 \mathrm{~B}) \text {. Marked bimodal } \\
\text { fabric. Internal structure of the pumiceous ash beds (commonly centimetres thick) marked by }\end{array}$ & $\begin{array}{l}\text { Deposition resulted from mixing of water-supported gravity flows of volcaniclastic } \\
\text { debris and settling from suspension of submarine rhyolitic volcanic products. The } \\
\text { facies is similar to medial facies of the volcaniclastic apron described by Rinaldi and }\end{array}$ \\
\hline Present in V.U. IV. & $\begin{array}{l}\text { diffuse, plane-parallel and low-angle cross-beds. Local small-scale discordances and } \\
\text { truncations. Normally graded pumice beds. } \\
\text { Bedding distorted by occurrence of pumice blocks displaying internal polyhedral joints. } \\
\text { Mantling of pumice blocks by ash laminae. }\end{array}$ & $\begin{array}{l}\text { Campos Venuti (2003). } \\
\text { Bimodal fabric related to the different behaviours of pumice blocks to float within the } \\
\text { water column, then sinking when density of blocks increases by water absorption. }\end{array}$ \\
\hline $\begin{array}{l}\text { Volcanic blocks resting } \\
\text { on terrigenous deposits }\end{array}$ & $\begin{array}{l}\text { The volcanic blocks }(0.20-4.40 \mathrm{~m}) \text { occur aligned at a same stratigraphic level, resting on } \\
\text { wave-rippled sandstone and siltstone (Table 1) that show local soft- sediment deformation } \\
\text { due to loading of the volcanic blocks. }\end{array}$ & $\begin{array}{l}\text { Drift of volcanic blocks after fragmentation of exposed dacite-andesite lava flows } \\
\text { accumulated in a coastal environment. Accumulation of the } \\
\text { volcanic blocks near the coastline as indicated by wave-rippled terrigenous }\end{array}$ \\
\hline Present in the lower part of D.U. III & $\begin{array}{l}\text { Compositionally the volcanic blocks are dacite-andesite and display internal fluidal } \\
\text { structure. }\end{array}$ & deposits at the base of the blocks. \\
\hline
\end{tabular}


Table 3

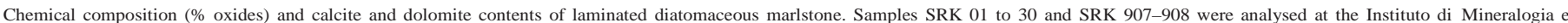

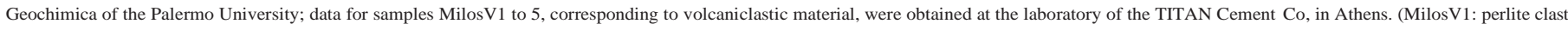

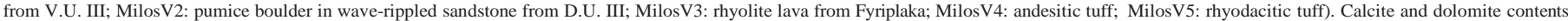
were determined at the Laboratory of Mineralogy and Geochemistry of the University Autonoma of Madrid.

\begin{tabular}{|c|c|c|c|c|c|c|c|c|c|c|c|c|c|}
\hline Sample & $\mathrm{SiO}_{2}$ & $\mathrm{TiO}_{2}$ & $\mathrm{Al}_{2} \mathrm{O}_{3}$ & $\mathrm{Fe}_{2} \mathrm{O}_{3}$ & $\mathrm{MnO}$ & $\mathrm{CaO}$ & Mgo & $\mathrm{Na}_{2} \mathrm{O}$ & $\mathrm{K}_{2} \mathrm{O}$ & $\mathrm{P}_{2} \mathrm{O}_{5}$ & L.O.I. & Calcite \% & Dolomite \% \\
\hline SRK 01 & 71.01 & 0.19 & 4.26 & 2.82 & 0.05 & 0.05 & 0.80 & 1.53 & 0.61 & 0.02 & 18.66 & - & - \\
\hline SRK 02 & 69.65 & 0.10 & 2.34 & 1.66 & 0.07 & 0.00 & 0.45 & 2.44 & 0.30 & 0.02 & 22.99 & - & - \\
\hline SRK 04 & 40.87 & 0.18 & 5.51 & 2.36 & 0.07 & 5.51 & 7.41 & 2.19 & 0.71 & 0.11 & 35.08 & - & 17 \\
\hline SRK 05 & 42.13 & 0.10 & 3.08 & 1.10 & 0.04 & 6.39 & 6.88 & 1.40 & 0.49 & 0.17 & 38.22 & - & 16 \\
\hline SRK 06 & 70.74 & 0.16 & 2.52 & 4.30 & 0.23 & 1.35 & 0.05 & 2.24 & 0.39 & 0.00 & 18.02 & - & - \\
\hline SRK 07 & 42.82 & 0.16 & 4.13 & 3.96 & 0.04 & 7.29 & 4.97 & 1.02 & 0.64 & 0.06 & 34.90 & - & 15 \\
\hline SRK 08 & 35.83 & 0.15 & 3.67 & 1.68 & 0.05 & 13.61 & 6.15 & 1.02 & 0.65 & 0.12 & 37.06 & 10 & 16 \\
\hline SRK 09 & 39.46 & 0.18 & 5.15 & 2.24 & 0.05 & 13.53 & 4.53 & 1.28 & 0.68 & 0.14 & 32.75 & 16 & 15 \\
\hline SRK 10 & 53.81 & 0.19 & 4.33 & 2.28 & 0.05 & 11.89 & 2.98 & 1.02 & 0.71 & 0.12 & 22.62 & 11 & 8 \\
\hline SRK 11 & 45.35 & 0.11 & 2.67 & 1.63 & 0.07 & 14.25 & 2.45 & 1.00 & 0.43 & 0.11 & 31.94 & 20 & 8 \\
\hline SRK 13 & 54.48 & 0.11 & 2.78 & 2.10 & 0.03 & 4.70 & 2.30 & 1.29 & 0.45 & 0.03 & 31.75 & 5 & 8 \\
\hline SRK 14 & 48.87 & 0.15 & 3.02 & 3.45 & 0.05 & 11.17 & 3.98 & 0.99 & 0.56 & 0.03 & 27.65 & 13 & 14 \\
\hline SRK 15 & 61.47 & 0.20 & 4.20 & 3.98 & 0.04 & 11.25 & 0.81 & 0.98 & 0.71 & 0.03 & 16.34 & 20 & - \\
\hline SRK 16 & 35.08 & 0.09 & 2.51 & 1.37 & 0.03 & 16.05 & 0.41 & 1.67 & 0.31 & 0.03 & 42.44 & 29 & - \\
\hline SRK 17 & 68.53 & 0.16 & 3.25 & 2.26 & 0.05 & 8.30 & 1.11 & 0.98 & 0.59 & 0.14 & 14.65 & 14 & b5 \\
\hline SRK 17b & 28.54 & 0.11 & 3.94 & 1.17 & 0.06 & 12.64 & 4.70 & 1.57 & 0.48 & 0.11 & 46.68 & 11 & 18 \\
\hline SRK 18 & 62.26 & 0.15 & 3.27 & 2.76 & 0.04 & 11.60 & 0.62 & 0.97 & 0.56 & 0.05 & 17.73 & 20 & - \\
\hline SRK 19 & 57.49 & 0.15 & 3.54 & 2.93 & 0.06 & 9.91 & 1.52 & 1.13 & 0.56 & 0.09 & 22.62 & 15 & 5 \\
\hline SRK 20 & 47.14 & 0.17 & 4.69 & 2.48 & 0.07 & 12.03 & 1.79 & 1.18 & 0.59 & 0.05 & 29.82 & 20 & 5 \\
\hline SRK 21 & 43.18 & 0.13 & 3.28 & 1.86 & 0.04 & 11.14 & 5.53 & 1.05 & 0.76 & 0.10 & 32.91 & 19 & b5 \\
\hline SRK 22 & 57.86 & 0.40 & 11.02 & 5.91 & 0.05 & 7.47 & 2.74 & 0.98 & 1.98 & 0.02 & 11.59 & 8 & 9 \\
\hline SRK 28 & 38.32 & 0.18 & 7.23 & 2.22 & 0.06 & 16.80 & 2.24 & 1.18 & 1.38 & 0.05 & 30.36 & 28 & b5 \\
\hline SRK 38 & 55.08 & 0.25 & 6.75 & 3.83 & 0.05 & 12.58 & 1.39 & 0.98 & 1.11 & 0.03 & 17.96 & 20 & b5 \\
\hline SRK 39 & 53.77 & 0.13 & 2.69 & 2.71 & 0.08 & 9.04 & 0.00 & 2.46 & 0.43 & 0.03 & 28.86 & 17 & - \\
\hline SRK 41 & 49.77 & 0.22 & 8.08 & 3.65 & 0.04 & 13.32 & 1.75 & 1.04 & 1.58 & 0.02 & 20.52 & 22 & b5 \\
\hline SRK 42 & 48.77 & 0.18 & 5.91 & 2.60 & 0.08 & 14.88 & 0.00 & 1.50 & 1.12 & 0.02 & 24.94 & 24 & - \\
\hline SRK 45 & 63.67 & 0.15 & 3.49 & 3.83 & 0.08 & 6.74 & 0.04 & 1.86 & 0.55 & 0.02 & 19.58 & 11 & - \\
\hline SRK 46 & 57.77 & 0.14 & 3.75 & 2.61 & 0.06 & 12.06 & 0.42 & 1.38 & 0.52 & 0.01 & 21.26 & 20 & - \\
\hline SRK 907 & 45.14 & 0.10 & 4.47 & 1.72 & 0.03 & 11.57 & 0.36 & 3.25 & 0.60 & 0.07 & 32.68 & 18 & - \\
\hline SRK 908 & 57.23 & 0.18 & 5.04 & 1.62 & 0.05 & 13.72 & 1.83 & 0.99 & 0.11 & 0.10 & 19.14 & 21 & b5 \\
\hline MilosV1 & 71.47 & n.d. & 14.26 & 1.79 & n.d. & 1.87 & 0.61 & 2.37 & 3.05 & 0.12 & 4.70 & - & - \\
\hline MilosV2 & 65.22 & n.d. & 15.22 & 3.50 & n.d. & 3.52 & 1.15 & 3.62 & 2.66 & 0.17 & 4.02 & - & - \\
\hline MilosV3 & 73.48 & n.d. & 13.27 & 1.49 & n.d. & 1.53 & 0.64 & 3.74 & 3.78 & 0.02 & 1.89 & - & - \\
\hline MilosV4 & 59.86 & n.d & 15.63 & 5.31 & n.d. & 6.54 & 1.48 & 5.66 & 1.10 & n.d. & 3.58 & - & - \\
\hline MilosV5 & 72.14 & n.d & 14.95 & 1.88 & n.d. & 1.84 & 0.55 & 2.33 & 3.51 & n.d. & 3.30 & - & - \\
\hline
\end{tabular}

n.d.: not determined.

in submarine depositional environments, from shoreface to basinal. The occurrence of burrowing ichnofacies in laminated diatomaceous marlstone points to episodes of improved benthic oxygenation in sedimentary facies indicative of a generally oxygen-deficient setting. This feature, together with the common cyclic association of laminated marlstone and burrowed sandy limestone, suggests that the basins were just some tens to a few hundreds of metres deep.

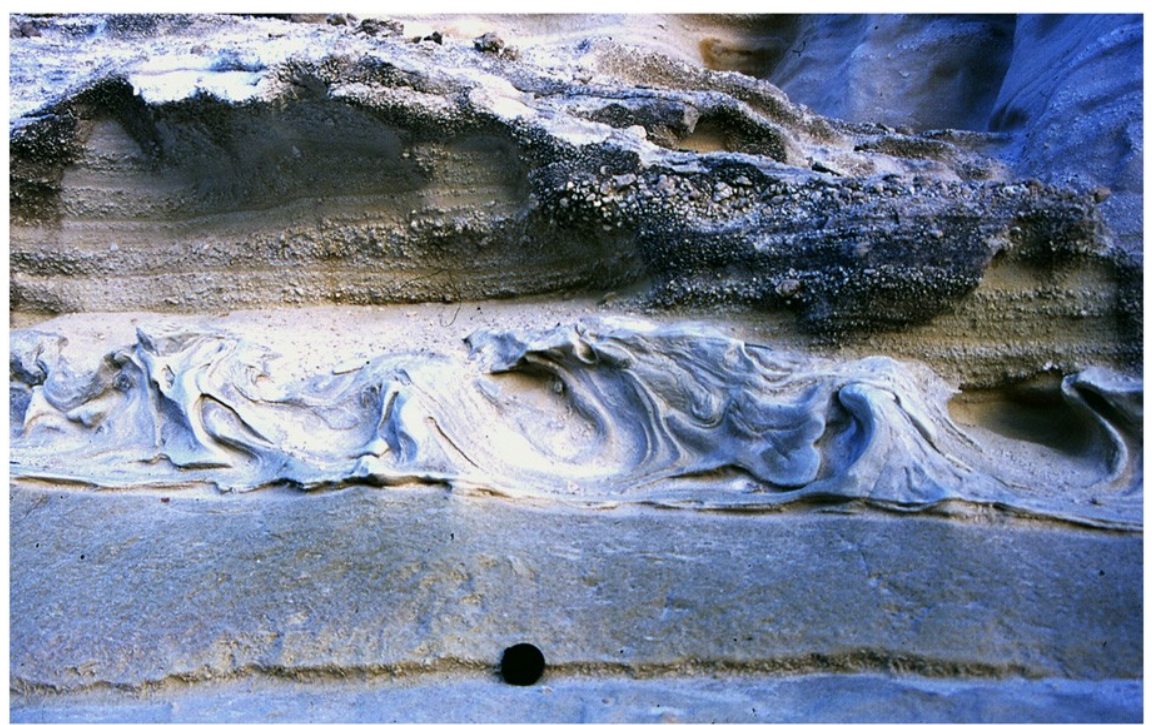

Fig. 10. Convolute bedding in fine-grained ash pumice deposits (lower part of Volcaniclastic Unit III in Sarakiniko). Lens cap for scale is $7 \mathrm{~cm}$. 


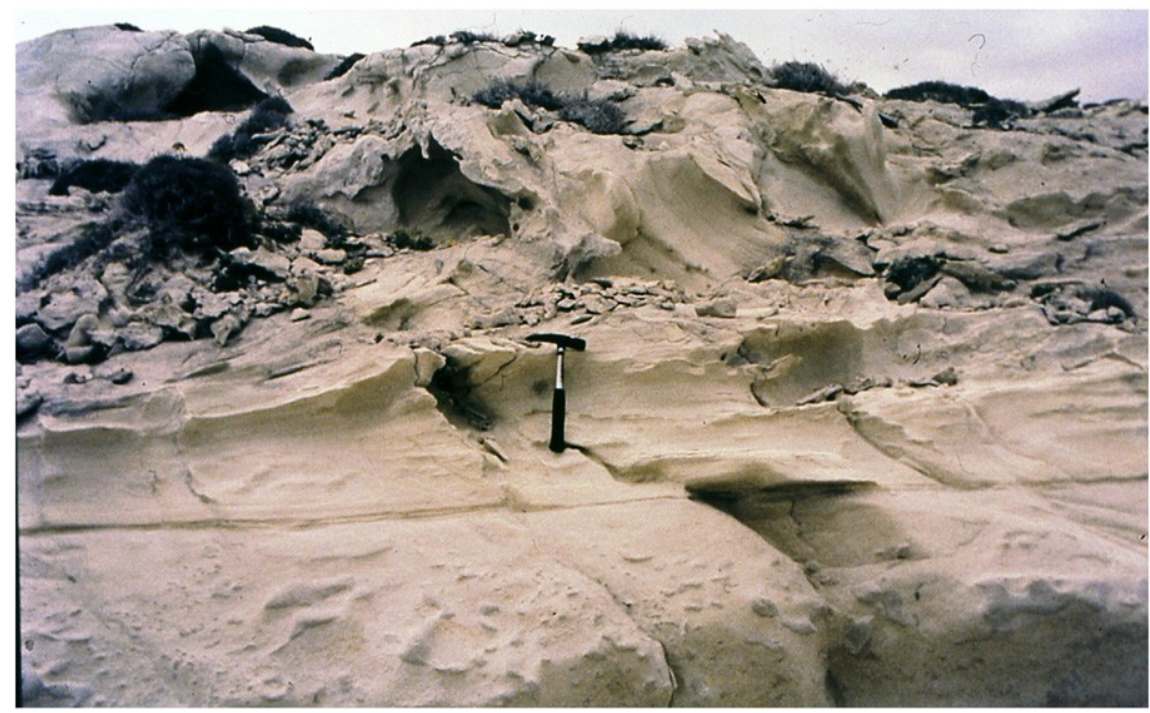

Fig. 11. Soft-sediment deformation of fossiliferous/pumiceous marlstone attributed to earthquakes (lower part of Volcaniclastic Unit III). The marlstone beds show a sharp, well- defined contact over finegrained volcaniclastic deposits. Over the contact, the marlstone becomes progressively deformed. Hammer is $30 \mathrm{~cm}$ long.

Some palaeoecological differences during deposition of diatomite units can be determined on the basis of micropalaeontological con- tents. Thus, Diatomite Unit II is marked by a high content of lower photic zone nannofossil species Florisphaera profunda (Okada and Honjo, 1973) that has proven to be a very reliable proxy to locate the nutricline-thermocline level (Molfino and Mcintyre, 1990) indi- cating marked stratification of the water column and low produc- tivity within the surface layer (e.g. Castradori, 1993). The presence of Braarudosphaera spp. points to fresh-water input during deposition of the diatomaceous marlstone (Negri and Giunta, 2001; Triantaphyllou et al., 2009a, 2009b, 2010). For Diatomite Unit III, high abundance of small nannofossil Gephyrocapsa spp. along with the presence of planktonic foraminifer $G$. inflata are indicative of a marine environment characterised by highly productive cool waters (e.g. Triantaphyllou et al., 2010).

Rhyolitic intrusions resulting in felsic cryptodome-pumice cone volcanoes (Stewart and McPhie, 2006) accounted for vast accumula- tion of coarse- to fine-grained pumice deposits that formed shoaling areas on seafloor. The resulting likely palaeogeography is a number of silled basins where laminated diatomaceous marlstone accumu- lated (Fig. 13). Extensive reworking of volcanic grains, mainly glass shards, by shallow marine currents and gravity flows is recorded
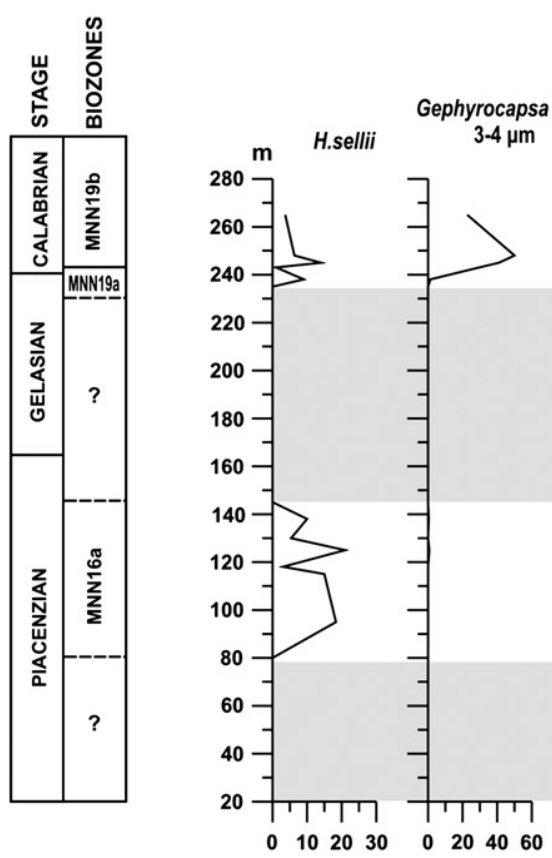

Gephyrocapsa spp.

C.macintyrei B.bigelowil

P.lacunosa $\underset{<3 \mu \mathrm{m}}{\text { small Gephyrocapsa spp. }}$

F.profunda
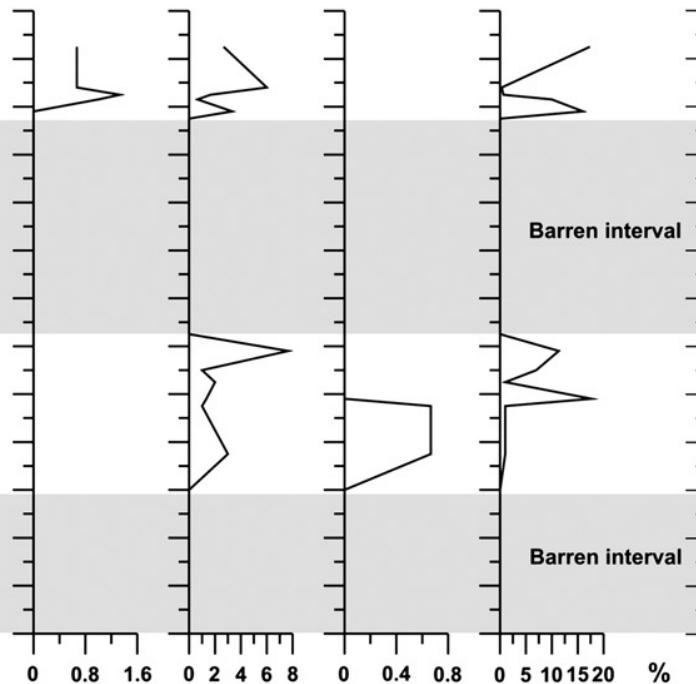

abundant 
Table 4

Summary of microfossils from the upper Pliocene-lower Pleistocene succession of northern Milos. Data on macrofossils for Diatomite Unit III are from Sonder (1924) and Fytikas (1977).

\begin{tabular}{|c|c|c|c|c|}
\hline \multicolumn{2}{|c|}{ Lithological units Calcareous nannofossils } & Diatoms & \multirow{2}{*}{\multicolumn{2}{|c|}{$\begin{array}{l}\text { Planktonic-benthic } \\
\text { foraminifera }\end{array}$}} \\
\hline & & & & \\
\hline Diatomite Unit I & & $\begin{array}{l}\text { Rophadolia, Actinocyclus spp., } \\
\text { Rhizosolenia, Grammatophora }\end{array}$ & Barren & \\
\hline Diatomite Unit II & $\begin{array}{l}\text { Helicosphaera sellii, Calcidiscus } \\
\text { macintyrei, Pseudoemiliania lacunosa, } \\
\text { Braarudosphaera spp., very rare Discoaster } \\
\text { asymmetricus, D. tamalis, } \\
\text { D. triradiatus, rare small Gephyrocapsa spp., } \\
\text { abundant Florisphaera profunda }\end{array}$ & $\begin{array}{l}\text { Rophadolia, } \\
\text { Thalassionema, } \\
\text { Rizhosolenia, Thalassiosira, } \\
\text { Nitzschia, Hemidiscus, } \\
\text { Actinocyclus }\end{array}$ & $\begin{array}{l}\text { Globigerina bulloides, G. falconensis, } \\
\text { G. quinqueloba, Globigerinoides } \\
\text { ruber, } \\
\text { G. quinqueloba, Neogloboquadrina } \\
\text { pachyderma, Orbulina universa, } \\
\text { Cibicides lobatulus }\end{array}$ & \\
\hline Diatomite Unit III & $\begin{array}{l}\text { Helicosphaera sellii, Calcidiscus macintyrei, } \\
\text { Pseudoemiliania lacunosa, Gephyrocapsa spp. } \\
>4 \text { m, abundant small Gephyrocapsa spp. }\end{array}$ & $\begin{array}{l}\text { Stephanopyxix and Amphora } \\
\text { forms. Rizhosolenia, } \\
\text { Rophadolia, Nitzschia, } \\
\text { Hemidiscus }\end{array}$ & $\begin{array}{l}\text { Globigerinoides saculifer, } \\
\text { Globigerinella aequilateralis } \\
\text { and Globorotalia inflata. }\end{array}$ & $\begin{array}{l}\text { Bivalves (Chlamys spp., Pecten, } \\
\text { Isocardia, Solecardia, Pinna, Ostrea, } \\
\text { Chama, Lucinopsis), scaphopods } \\
\text { (Dentalium), gastropods (Scala), } \\
\text { brachiopods (Terebratula spp.), } \\
\text { echinoids (Arbacina, Psammechinus, } \\
\text { Schizaster, Lytechinus, Brissopsis, } \\
\text { Prostagantus) }\end{array}$ \\
\hline DiatomiteUnitIV & & $\begin{array}{l}\text { Stephanopyxix and Amphora } \\
\text { forms. Rizhosolenia, } \\
\text { Rophadolia, Nitzschia, } \\
\text { Hemidiscus }\end{array}$ & $\begin{array}{l}\text { Globigerina bulloides, G. quinqueloba, } \\
\text { G. falconensis, Globigerinoides } \\
\text { ruber, Neogloboquadrina } \\
\text { pachyderma }\end{array}$ & \\
\hline
\end{tabular}

within the lithic laminae of the diatomaceous marlstone as well as in the terrigenous fraction of the remaining fossiliferous sedimentary lithofacies.

The location of eruption centres changed throughout the late Pliocene-early Pleistocene in northern Milos. Submarine cryptodome- pumice cone volcanoes, e.g. the Filakopi cryptodome located east of the study area, were emplaced at several points where Milos Island is now situated (Stewart and McPhie, 2006). Rinaldi and Campos Venuti (2003) identified the Bombarda volcano, south of the study area. Other eruption centres, in particular those causing accumula- tion of the lowermost volcaniclastic units, may be located in the islets of Polyegos and Kimolos, a few kilometres north of Milos (Francalanci et al., 2007), or are currently submarine.
Accommodation space available for both development and distri- bution of the upper Pliocene-lower Pleistocene rocks of northern Milos resulted from the combined effect of submarine volcanism and sea-level changes. Several episodes of sea-level rise and drop can be identified on the basis of local unconformities and/or major truncations throughout the stratigraphic succession. In the following paragraphs, a summary of stratigraphic discontinuities and major depositional changes (named 'events' in Fig. 14) from bottom to top of the sequence is presented.

Deposits from Diatomite Unit I and Volcaniclastic Unit II are bounded by a sharp erosive contact (Event A; Fig. 14) that resulted from redeposition of clast- to sand-sized pumiceous deposits over a relatively deep-marine diatomaceous marlstone. This event likely

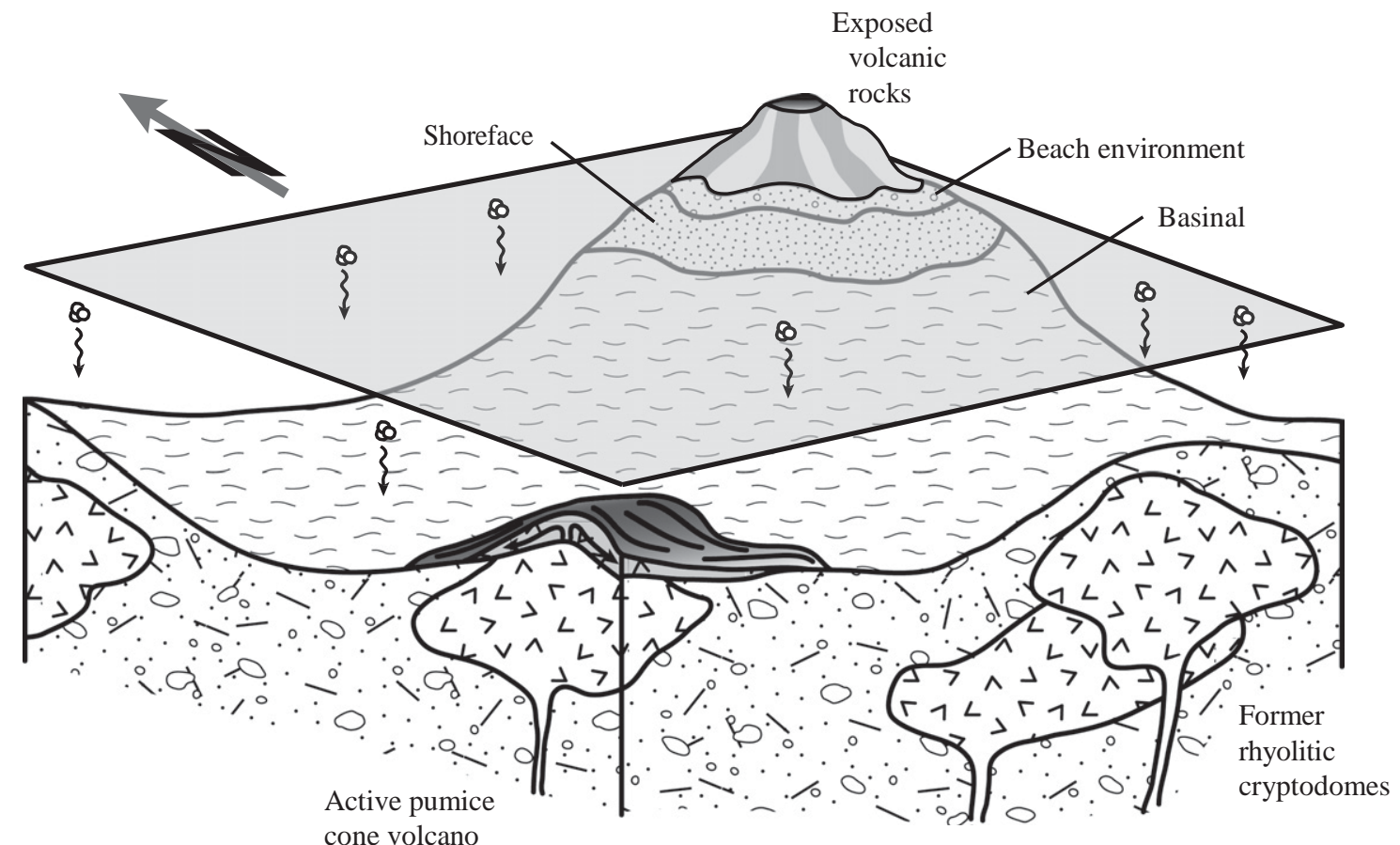

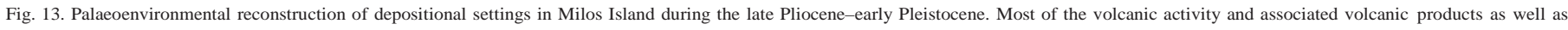
sedimentation processes took place in a marine environment. Locations of main volcanic intrusion centres are approximate. Graphic design is inspired on Stewart and McPhie (2006). 
indicates sea-level drop and/or readjustment of the submarine de- posits due to volcanic-induced instability. Volcaniclastic Unit I can be tentatively correlated with the Agios Konstatinos Pumice Breccia (see Fig. 2 in Stewart and McPhie, 2004).

After deposition of a thick sequence of alternating laminated diatomaceous marlstone and sandy limestone deposits, the development of crossstratified, brachiopod-rich (Terebratula spp.) sandstone facies (Event B; Fig. 14) points to a stage of remarkable shallowing. This facies is representative of beach deposits directly overlying shoreface and basinal facies characteristic of Diatomite Unit II. An up section change from the foreshore facies to shoreface sandy limestone and further accumulation of coarse pumice breccia of the lower part of Volcaniclastic Unit III indicates rapid sea-level rise. These deposits can be stratigraphically correlated with the Filakopi Pumice Breccia (FPB) of Stewart and McPhie (2004) who provided an upper age limit for the submarine pumice breccias at about $2.66 \pm 0.07$ $\mathrm{Ma}$, similar to that obtained by SHRIMP $\mathrm{U}-\mathrm{Pb}$ in zircon dating of the Kalogeros dacitic cryptodome (Stewart and McPhie, 2003a, 2006).

A sharp contact between volcaniclastic and shallow-water fossiliferous deposits at the top of the coarse pumice breccia facies indicates an internal truncation in Volcaniclastic Unit III (Event C; Fig. 14), probably related to large-scale tilting. The fossiliferous de- posits above the contact are up to $8 \mathrm{~m}$ thick and show rapid lateral thinning into $0.60 \mathrm{~m}$ thick beds, and even disappear under a pack- age of volcaniclastic deposits. This feature together the strong soft- sediment deformation of the fossiliferous sedimentary beds points to readjustment of the geometry of seafloor prior to the emplace- ment of a felsic cryptodome-pumice cone volcano. According to this stratigraphic scheme, most of Volcaniclastic Unit III can be cor- related with the Papafragas Formation (Fytikas, 1977; see Fig. 2 in Stewart and McPhie, 2004).

The onset of shallow marine sedimentation of Diatomite Unit III (Event D; Fig. 14) followed rapid accumulation of the pumiceous de- posits of Volcaniclastic Unit III. The contact between the two units is sharp. Deposition of fossiliferous-rich, burrowed sandy limestone above the contact is underlined by the occurrence of aligned volcanic blocks. The Gelasian/Calabrian boundary (1.805 Ma) has been identi- fied within the laminated diatomaceous marlstone deposits of Diato- mite Unit III. The dating allows stratigraphic correlation with previously defined stratigraphic formations in other Greek locations where the lower Pleistocene record is exposed (e.g. Papanikolaou et al., 2011). The sedimentary deposits of Diatomite Unit III can be cor- related with the Sarakiniko Formation.

The stratified pumice deposits of Volcaniclastic Unit IV unconformably overlie the fossiliferous rocks of Diatomite Unit III (Event E; Fig. 14). The volcaniclastic deposits are interpreted to be related to the submarine eruption of the Bombardo volcano, dated as

$\sim$ 1.7 Ma (Rinaldi and Campos Venuti, 2003). An alternative interpre- tation suggests a genetic relation to the Korakia Andesite, dated at

1.8 Ma (Kondopoulou and Pavlides, 1990) but the predominance of felsic pumice blocks and ash in Volcaniclastic Unit IV better conforms the former interpretation.

Deposition of Diatomite Unit IV represents the last episode of clearly marine sedimentation in northern Milos. Sedimentation over volcanic deposits of Volcaniclastic Unit IV (Event F; Fig. 14) started directly with vaguely laminated marlstone that passes rap- idly into laminated diatomaceous marlstone. This suggests rela- tively deep sea depositional conditions for both the top of the volcaniclastic unit and the diatomaceous deposits. The rest of Diat- omite Unit IV reflects changes in water depth trending to progres- sively shallow water, as indicated by development of burrowed sandy limestone at the top of the unit. The transition from the fos- siliferous marine deposits to Volcaniclastic Unit V, which shows reworking by shallow-water currents, is mainly covered, thus pro- hibiting clear interpretation of the evolution of the depositional setting.

\section{Conclusions}

The upper Pliocene-lower Pleistocene succession of northern Milos records an alternation of explosive volcanic products and fossiliferous sedimentary rocks. Four main sedimentary facies representative of var- ied submarine depositional environments are recognised: i) laminated diatomaceous marlstone, ii) massive sandy limestone, iii) cross- stratified, brachiopod-rich (Terebratula spp.) sandstone, and iv) wave- rippled sandstone and siltstone.

Laminated diatomaceous marlstone is the most common sedi- mentary deposit and consists of lithic and biogenic couplets where reworked volcanic grains are associated with dense accumulations of diatoms, calcareous nannofossils, and foraminifera. Deposition of diatomaceous marlstone took place in a number of silled, relatively shallow basins where water stratification and oxygen-deficient con- ditions prevailed. The presence of local burrows (Ophiomorpha?) at several intervals of the laminated diatomaceous deposits points to episodes of improved benthic oxygenation. Cyclic facies association of the diatomaceous marlstone with burrowed sandy limestone indi- cates oscillations in water depth that may have resulted from sea- level changes and/or emplacement of submarine volcanic cones.

Volcanic activity during the development of the upper Pliocene- lower Pleistocene succession was closely related to the emplacement of cryptodome-pumice cone volcanoes. Rhyolitic intrusion centres produced vast accumulations of coarse pumice breccia and associated finer-grained pumiceous deposits that underwent extensive rework- ing by shallow-marine and turbidite flows.

Six major events reflecting episodes of volcanic emplacement, changes in sea-floor morphology and sea-level changes are recorded throughout the succession. On the basis of calcareous nannofossils, the Gelasian/Calabrian boundary (formerly Pliocene-Pleistocene boundary) is identified within Diatomite Unit III. The dating is consistent with exist- ing radiometric data and allows stratigraphic correlation with previously defined stratigraphic formations in Milos Island and other Greek loca- tions where the lower Pleistocene stratigraphic record is exposed.

\section{Acknowledgements}

Special thanks are owed to the following colleagues who provided both scientific and technical assistance. Juan Usera (University of Valen- cia) is thanked for his help in determination of planktonic foraminifera. María José López-García (National Museum of Natural Sciences, Ma- drid) provided scientific guidance on the study of diatom assemblages. Adriana Bellanca and Rodolfo Neri (University of Palermo) participated in profitable scientific discussion and helped with petrographical and geochemical studies. Ulrich Lutat (Silver \& Baryte Co) provided field as- sistance. Thanks are given to Dimitris Fragoulis, from TITAN Co for his kindness in providing XRF analyses. Manuel Pozo (University Autonoma of Madrid) is thanked for helping in XRD determinations. Jesús Caracuel (University of Alicante), who has unfortunately since passed away, helped in ichnological analysis. María José Huertas is especially thanked for her comments on volcanological processes and products. We are also indebted to Thomas Stevens (Royal Holloway, London) who helped in refining the final version of the paper. Technical and sci- entific assistance by Pedro Castiñeiras is greatly appreciated. Two anon- ymous reviewers and the Editor-in-Chief Finn Surlyk are thanked for their constructive and valuable reviews that considerably improved an earlier version of the manuscript. The work has been supported by Projects PB97-0244 and CGL2008-05813-C02-02 (Spanish Ministry of Science and Innovation), by the Greek General Secretariat of Re- search \& Technology (GSRT), and it has benefited from Greek- Spanish bilateral cooperation programmes. For financial support we are also indebted to the University Complutense of Madrid (Research Group BSCH UCM-910607). 

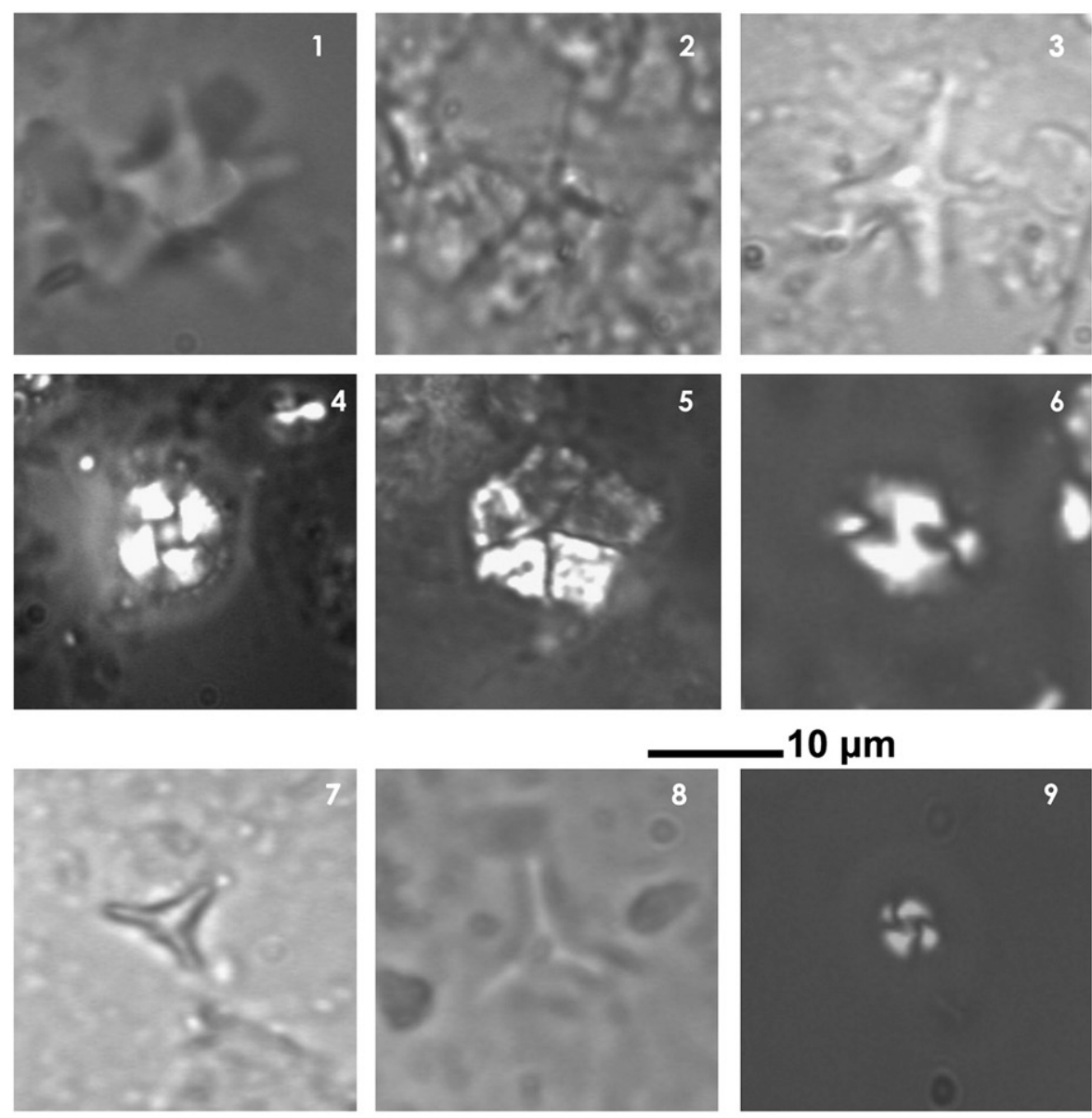

$10 \mu \mathrm{m}$
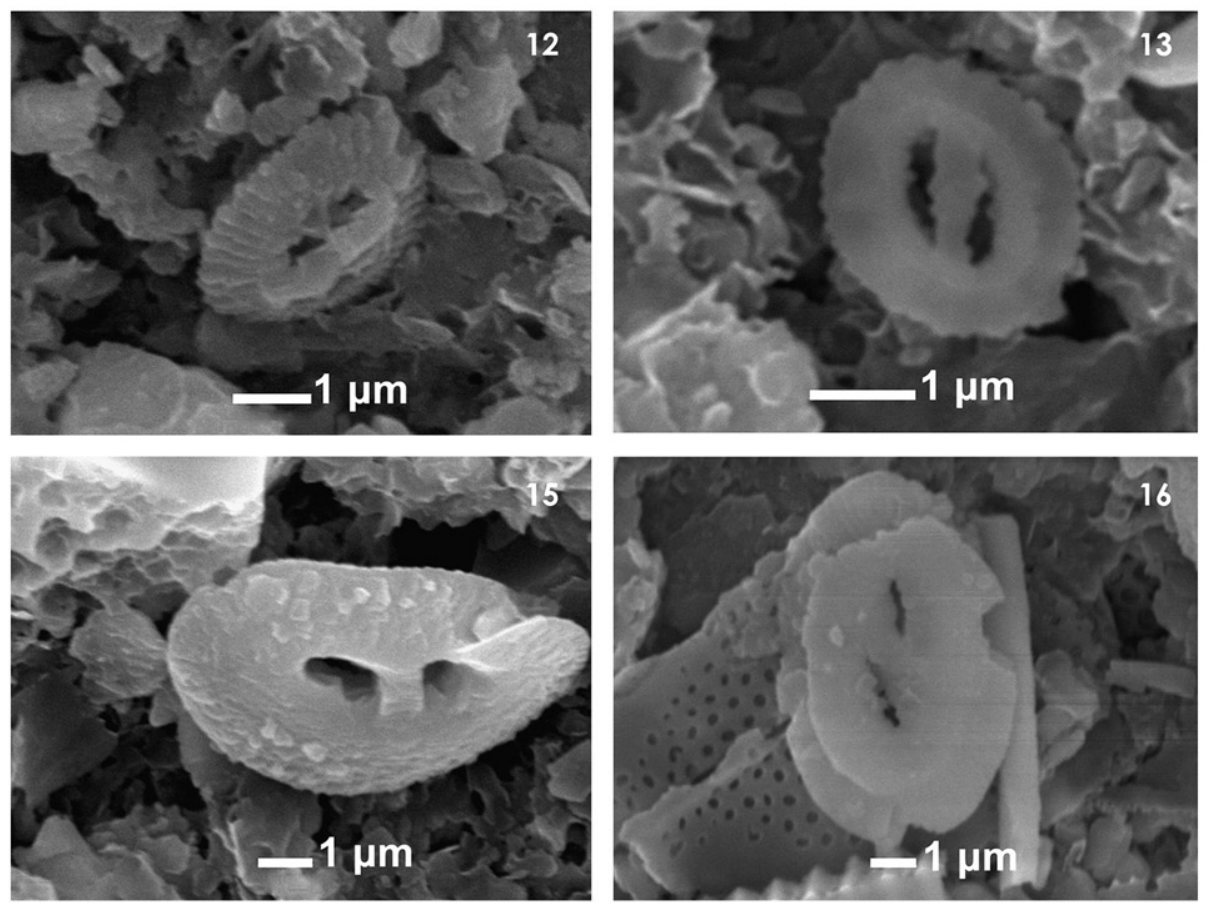
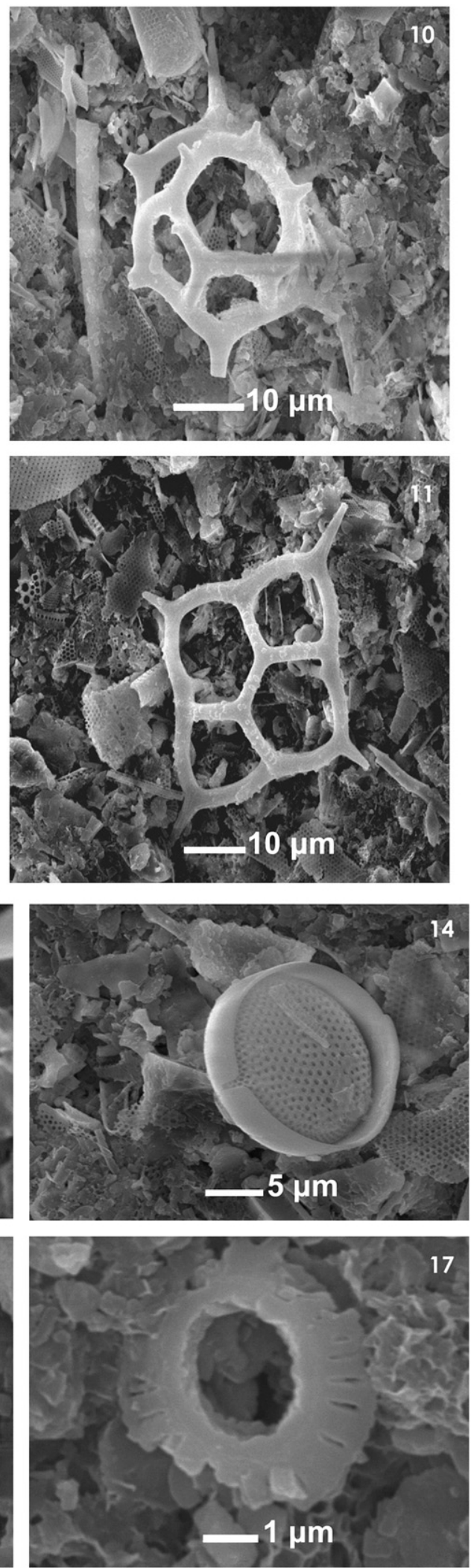


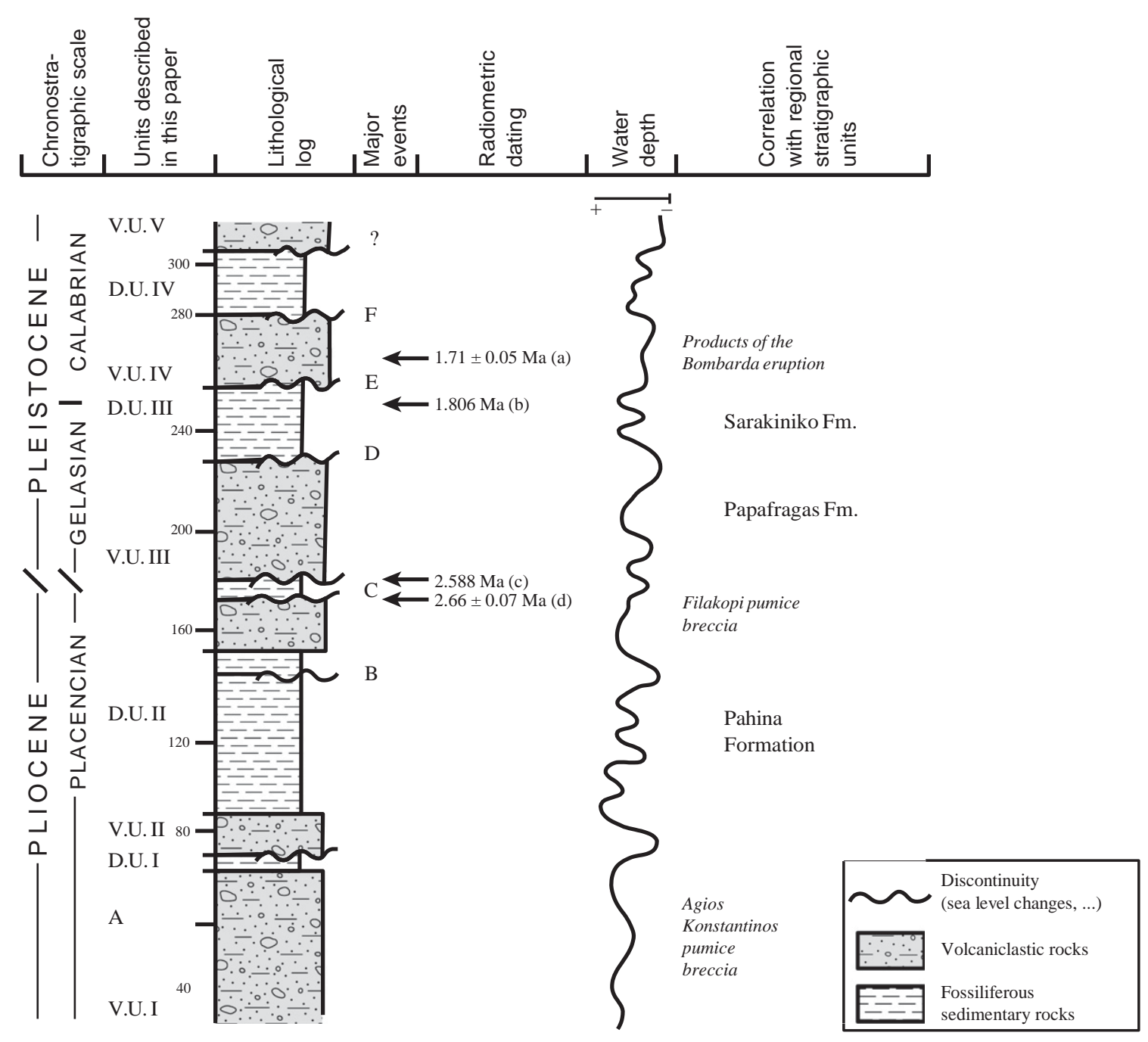

Fig. 14. Summary of major geological events recorded in the upper Pliocene-lower Pleistocene succession of northern Milos. References for radiometric dating are as follows: (a) Rinaldi and Campos Venuti (2003); based on Fytikas et al. (1986); (b) Gelasian/Calabrian boundary; Gibbard et al. (2009); (c) Stewart and McPhie (2006); (d) Pliocene/ Pleistocene boundary; Gibbard et al. (2009).

\section{References}

Angelier, J., Lyberis, N., Le Pichon, X., Barrier, E., Huchon, P., 1982. The tectonic development of the Hellenic Arc and the Sea of Crete: a synthesis. Tectonophysics 86, 159-196.

Bellas, S., Frydas, D., 1994. Calcareous and siliceous phytoplankton stratigraphy from Neogene deposits of Milos Island (Cyclades, Greece). Bulletin of the Geological Society of Greece 30, 363-372.

Castradori, D., 1993. Calcareous nannofossils and the origin of Eastern Mediterranean sapropels. Paleoceanography 8, 459-471.

Collinson, J., 1994. Sedimentary deformational structures. In: Maltman, A. (Ed.), The Geological Deformation of Sediments. Chapman \& Hall, London, pp. 95-125.

Francalanci, L., Vougioukalakis, G.E., Fytikas, M., 2007. Petrology and volcanology of Kimolos and Polyegos volcanoes within the context of the South Aegean Arc, Greece. In: Beccaluva, I., Bianchini, G., Wilson, M. (Eds.), Cenozoic volcanism in the Mediterranean area: Geol Soc America Spec. Paper, 418, pp. 33-65.
Frydas, D., 1992. Silicoflagellés et Diatomées du Pleistocène inferieur de l'île de Milos: coupe d'Adamas SE (Cyclades, Grèce). Géologie Méditerranéenne 19, 231-247.

Frydas, D., 1996a. Silicoflagellate stratigraphy for Neogene to Quaternary marine sediments in Greece. Newsletters on Stratigraphy 32, 99-116.

Frydas, D., 1996b. Upper Zanclean silicoflagellates from Milos Island (Cyclades, Greece) Journal of Nannoplankton Research 18, 61-67.

Fytikas, M., 1977. Geological Map of Milos 1:25 000. Institute of Geology and Mineral Exploration(IGME), Athens, Greece.

Fytikas, M., Vougioukalakis, G., 1995. Pre-meeting Field-trip to Milos. I.G.C.P. Project 356, 3rd Annual Meeting, IUGS-UNESCO, Guidebook.

Fytikas, M., Vougioukalakis, G. (Eds.), 2005. The South Aegean Active Volcanic arc. Present knowledge and future perspectives. : Developments in Volcanology, 7. Elsevier Publ. Co., Amsterdam.

Fytikas, M., Giuliani, O., Innocenti, F., Marinelli, G., Mazzuoli, R., 1976. Geochronological data on recent magmatism of the Aegean Sea. Tectonophysics 31, T29-T34.

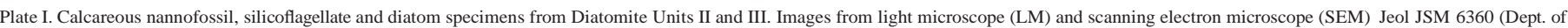

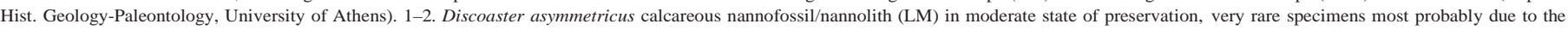

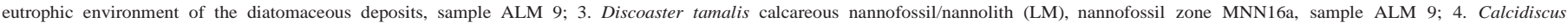

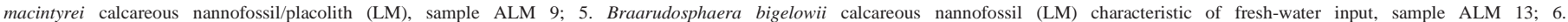

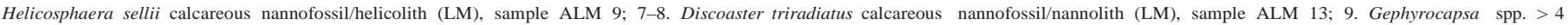

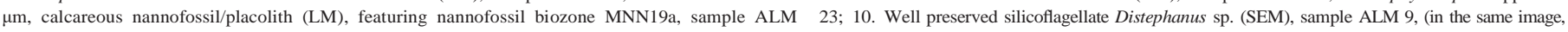

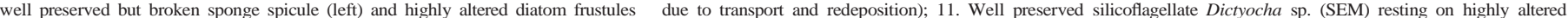

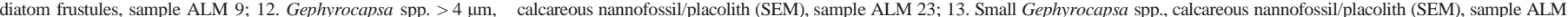

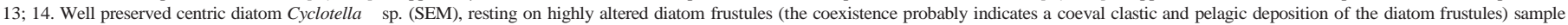

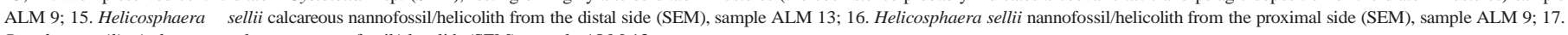
Pseudoe- miliania lacunose calcareous nannofossil/placolith (SEM), sample ALM 13. 
Fytikas, M., Innocenti, F., Kolios, N., Manetti, P., Mazzuoli, R., Poli, G., Rita, F., Villari, L., 1986. Volcanology and petrology of volcanic products from the island of Milos and the neighbouring islets. Journal of Volcanology and Geothermal Research 28, 297-317.

Gibbard, P.L., Head, M.J., Walker, M.J.C., The Subcommission on Quaternary Stratigraphy, 2009. Formal ratification of the Quaternary System/Period and the Pleistocene Series/Epoch with a base at 2.58 Ma. Journal of Quaternary Science. doi:10,1002/ jqs.1338.

Jackson, J.A., 1994. Active tectonics of the Aegean region. Annual Review of Earth and Planetary Sciences 22, 239-271.

Jones, A.P., Omoto, K., 2000. Towards establishing criteria for identifying trigger mech- anisms for soft-sediment deformation: a case study of Late Pleistocene lacustrine sands and clays, Onikobe and Nakayamadaira Basins, northeastern Japan. Sedi- mentology 47, 1211-1226.

Kondopoulou, D.P., Pavlides, S.B., 1990. Paleomagnetic and neotectonic evidence for different deformation patterns in the south Aegean Volcanic Arc: the case of Milos Island. Proceedings of the International Earth Science Congress on Aegean Regions, Izmir, pp. 210233.

Le Pichon, X., Angelier, J., 1979. The Aegean Sea. Philosophical Transactions of the Royal Society of London Series A 300, 357-372.

Lourens, L., Hilgen, F., Shackelton, N.J., Laskar, J., Wilson, D., 2004. The Neogene Period. In: Gradstein, F.M., Ogg, J.G., Smith, A.G. (Eds.), A Geological Time Scale. Cambridge Univ. Press, Cambridge, pp. 409-440.

McKenzie, D.P., 1978. Active tectonics of the Alpine Himalayan belt: the Aegean Sea and surrounding areas. Geophysical Journal of the Royal Astronomical Society 55, 217-254.

Meulenkamp, J.E., Wortel, M.J.R., Van Wamel, A.A., Spakman, W., Hoogerduyn Strating, E., 1988. On the Hellenic subduction zone and the geodynamic evolution of Crete since the late Middle Miocene. Tectonophysics 146, 203-215.

Molfino, B., Mcintyre, A., 1990. Precessional forcing of nutricline dynamics in the Equatorial Atlantic. Science 249, 766-769.

Negri, A., Giunta, S., 2001. Calcareous nannofossil paleoecology in the sapropel S1 of the Eastern Ionian Sea: paleoceanographic implications. Palaeogeography, Palaeocli- matology, Palaeoecology 169, 101-112.

Okada, H., Honjo, S., 1973. The distribution of ocean coccolithophorids in the Pacific. Deep Sea Research 20, 355-374.

Owen, G., 1996. Experimental soft-sediment deformation: structures formed by the liquefaction of unconsolidated sands and some ancient examples. Sedimentology 43, 279-293.

Papanikolaou, M., Triantaphyllou, M., Platzman, E., Gibbard, P., Macniocaill, C., Head, M.J., 2011 A well established Early-Middle Pleistocene marine sequence on SE Zakynthos island, Western Greece: magneto-biostratigraphic constraints and palaeoclimatic implications. Journal of Quaternary Science 26, 523-540.

Pe-Piper, G., Piper, D.J.W., 1989. Spatial and temporal variation in Late Cenozoic back- arc volcanic rocks, Aegean Sea region. Tectonophysics 169, 113-134.

Pe-Piper, G., Piper, D.J.W., 2005. The South Aegean active volcanic arc: relationships between magmatism and tectonics. In: Fytikas, M., Vougloukalakis, G. (Eds.), The South Aegean Active Volcanic arc. Present knowledge and future perspec- tives. : Developments in Volcanology, 7. Elsevier Publ. Co., Amsterdam.

Perch-Nielsen, K., 1985. Cenozoic calcareous nannofossils. In: Bolli, H.M., Saunders, J.B., PechNielsen, K. (Eds.), Plankton Stratigraphy. Cambridge Univ. Press, Cambridge, pp. 427-554.

Raffi, I., Backman, J., Fornaciari, E., Palike, H., Rio, D., Lourens, L., Hilgen, F., 2006. A review of calcareous nannofossil astrobiochronology encompassing the past 25 million years. Quaternary Science Reviews 25, 3113-3137.

Rinaldi, M., Campos Venuti, M., 2003. The submarine eruption of the Bombarda volcano, Milos Island, Cyclades, Greece. Bulletin of Volcanology 65, 282-293.

Rio, D., Fornaciari, E., Raffi, I., 1990. Late Quaternary through early Pleistocene calcareous nannofossils from the western equatorial Indian Ocean (Leg 115). ODP Proceed. Sci. Results, pp. 175-235.
Royden, L.H., Papanikolaou, D.J., 2011. Slab segmentation and late Cenozoic disrup- tion of the Hellenic arc. Geochemistry, Geophysics, Geosystems 12. doi:10.1029/ 2010GC003280.

Sancetta, C., 1996. Laminated diatomaceous sediments: controls on formation and strategies for analysis. In: Kemp, A.E.S. (Ed.), Palaeoclimatology and palaeoceano- graphy from laminated sediments: Geol. Soc. Spec. Publ., 116, pp. 17-21.

Schminke, H.U., 2004. Volcanism. Springer, Berlin. 324 pp.

Sonder, R.A., 1924. Zur geologie und petrographie der inselgruppe con Milos. Zeitschrift für Vulkanologie 8, 181-237.

Stamatakis, M.G., 2003. Characterization of biogenic amorphous silica deposits in Greece and their industrial potential. In: Eliopoulos, D.G., et al. (Ed.), Mineral Exploration and Sustainable Development, 2. Millpress, Rotterdam, pp. 927-930.

Stamatakis, M.G., Lutat, U., Regueiro, M., Calvo, J.P., 1996. Milos. The mineral island. Industrial Minerals, pp. 57-61. February 1996, London.

Stamatakis, M.G., Fragoulis, D., Antonopoulou, S., Stamatakis, G., 2010. The opaline silica-rich sedimentary rocks of Milos Island, Greece, and their behaviour as pozzolans in the manufacture of cement. Advances in Cement Research 22, 171-183.

Stewart, A.L., McPhie, J., 2003a. Internal structure and emplacement of an Upper Pliocene dacite cryptodome, Milos Island, Greece. Journal of Volcanology and Geothermal Research 124, 129-148.

Stewart, A.L., McPhie, J., 2003b. Facies architecture of the submarine-to-subaerial volcanic succession on Milos, Greece. International Conference on the South Aegean Active Volcanic Arc: Present Knowledge and Future Perspectives (SAAVA 2003), Book of Abstracts, 24.

Stewart, A.L., McPhie, J., 2004. An Upper Pliocene coarse pumice breccia generated by a shallow submarine explosive eruption, Milos, Greece. Bulletin of Volcanology 66, 15-28.

Stewart, A.L., McPhie, J., 2006. Facies architecture and Late Pliocene-Pleistocene evolu- tion of a felsic volcanic island, Milos, Greece. Bulletin of Volcanology 68, 703-726. Traineau, H.,

Dalabakis, P., 1989. Mise en evidence d'une éruption phréatique historique sur l'ile de Milos (Grèce). $247-252$.

Comptes Rendus de l' Academie des Sciences Paris 308,

Triantaphyllou, M.V., Antonarakou, A., Kouli, K., Dimiza, M., Kontakiotis, G., Papaniko- laou, M., Ziveri, P., Mortyn, P.G., Lianou, V., Lykousis, V., Dermitzakis, M.D., 2009a. Late GlacialHolocene ecostratigraphy of the south-eastern Aegean Sea, based on plankton and pollen assemblages. Geo-Marine Letters 29, 249-267.

Triantaphyllou, M., Ziveri, P., Gogou, A., Marino, G., Lykousis, V., Bouloubassi, I., Emeis, K.C., Kouli, K., Dimiza, M., Rosell-Mele, A., Papanikolaou, M., Katsouras, G., Nunez, N., 2009b. Late Glacial-Holocene climatic variability at the southeastern margin of the Aegean Sea. Marine Geology 266, 182-197.

Triantaphyllou, M.V., Antonarakou, A., Dimiza, M., Anagnostou, Ch., 2010. Calcareous nannofossils and planktonic foraminiferal distributional patterns during deposition of sapropels S6, S5 and S1 in the Lybian Sea (Eastern Mediterranean). Geo-Marine Letters 30, 1-13.

Tucker, M.E., 2001. Sedimentary Petrology, 3rd ed. Blackwell Science, Oxford. 262 pp. van Hinsbergen, D.J.J., Snel, E., Garstman, S.A., Marunteanu, M., Langereis, C.G., Wortel, M.J.R., Meulenkamp, J.E., 2004. Vertical motions in the Aegean volcanic arc: evidence for rapid subsidence preceding in situ volcanism. Marine Geology 209, 329-345.

Vincent, P., 2000. Volcanoes: from magmas to tephra and epivolcaniclastics. In: Leyrit, H. Montenat, Ch. (Eds.), Volcaniclastic Rocks, from Magmas to Sediments. Gordon and Breach Science Publishers, pp. 1-32.

Zeilinga de Boer, J., 1989. The Greek enigma: is development of the Aegean orogene dominated by forces related to subduction or obduction? In: Makris, J. (Ed.), Geological Aspects and Tectonic Evolution of Mediterranean Seas: Mar. Geol., 87, pp. 31-54. 